Review

\title{
Proteasome Subtypes and Regulators in the Processing of Antigenic Peptides Presented by Class I Molecules of the Major Histocompatibility Complex
}

\author{
Nathalie Vigneron ${ }^{1,2,3, *}$ and Benoît J. Van den Eynde ${ }^{1,2,3}$ \\ 1 Ludwig Institute for Cancer Research, Brussels 1200, Belgium; \\ E-Mail: benoit.vandeneynde@bru.licr.org \\ 2 WELBIO (Walloon Excellence in Life Sciences and Biotechnology), Brussels 1200, Belgium \\ 3 De Duve Institute, Université catholique de Louvain, Brussels 1200, Belgium \\ * Author to whom correspondence should be addressed; E-Mail: nathalie.vigneron@bru.licr.org; \\ Tel.: +32-2-7647558; Fax: +32-2-7647590.
}

Received: 30 July 2014; in revised form: 2 October 2014 / Accepted: 29 October 2014 /

Published: 18 November 2014

\begin{abstract}
The proteasome is responsible for the breakdown of cellular proteins. Proteins targeted for degradation are allowed inside the proteasome particle, where they are cleaved into small peptides and released in the cytosol to be degraded into amino acids. In vertebrates, some of these peptides escape degradation in the cytosol, are loaded onto class I molecules of the major histocompatibility complex (MHC) and displayed at the cell surface for scrutiny by the immune system. The proteasome therefore plays a key role for the immune system: it provides a continued sampling of intracellular proteins, so that CD8-positive T-lymphocytes can kill cells expressing viral or tumoral proteins. Consequently, the repertoire of peptides displayed by MHC class I molecules at the cell surface depends on proteasome activity, which may vary according to the presence of proteasome subtypes and regulators. Besides standard proteasomes, cells may contain immunoproteasomes, intermediate proteasomes and thymoproteasomes. Cells may also contain regulators of proteasome activity, such as the 19S, PA28 and PA200 regulators. Here, we review the effects of these proteasome subtypes and regulators on the production of antigenic peptides. We also discuss an unexpected function of the proteasome discovered through the study of antigenic peptides: its ability to splice peptides.
\end{abstract}

Keywords: antigenic peptides; proteasome; regulator; peptide splicing; processing; CTL 


\section{Introduction to the Ubiquitin Proteasome System}

The ubiquitin-proteasome system (UPS) is the major ATP-dependent protein degradation system in cells. It is essential to maintain cellular protein homeostasis and ensure the elimination of misfolded proteins (reviewed in $[1,2]$ ). Proteasome-dependent proteolysis is also essential to regulate a number of other cellular processes, such as cell differentiation, cell-cycle progression or apoptosis. Proteins targeted for degradation by the proteasome are tagged with polyubiquitin chains that are attached to lysine residues within the protein sequence. These ubiquitin-tagged proteins are recognized by the regulatory particle 19S (PA700), which is associated with the 20S proteasome catalytic core to form the $26 \mathrm{~S}$ proteasome. Upon degradation, these ubiquitin-tagged proteins are degraded into small peptides of about three to 22 amino acids [3], which can be further degraded by cytosolic peptidases to recycle the pool of amino acids [4]. The immune system takes advantage of this system to monitor cellular integrity. Thus, a fraction of the peptides released by proteasomal degradation is transferred into the lumen of the endoplasmic reticulum (ER) by a dedicated transporter, named TAP (transporter associated with antigen processing) [5]. Inside the ER, those peptides will be further trimmed by ER-resident proteases, and peptides of an appropriate size (8-10 amino acids) and sequence will then associate with class I molecules of the major histocompatibility complex (MHC). Peptide-MHC complexes are finally displayed at the cell surface for potential recognition by cytolytic T-lymphocytes (CTLs). CTLs are major sentinels poised to rapidly recognize and destroy cells expressing mutant, infectious or tumoral proteins. It is the display of peptides (named antigenic peptides) derived from such altered proteins that marks cells for CTL recognition. The sensitivity of CTL, which can recognize target cells expressing as little as 10 molecules of antigenic peptide [6], enables the detection of only subtle changes in the cellular protein content. The detailed characterization of the antigenic peptides recognized by anti-tumor CTL that were isolated from the blood or tumor of cancer patients has provided valuable insights into the processing of antigenic peptides $[7,8]$. Such peptides usually derive from mutated proteins $[9,10]$, from differentiation proteins [11,12] and from tumor proteins encoded by cancer-germline genes, such as the MAGE genes [13].

\section{Role of the Proteasome in Antigen Processing}

The involvement of the proteasome in the production of MHC class I peptides was originally stressed by the observation that the presentation of the model antigen, ovalbumin, was dependent on ubiquitination and, therefore, on the $26 \mathrm{~S}$ proteasome $[14,15]$. In line with this, MHC class I presentation was accelerated when the N-terminus of protein antigens was genetically modified with a bulky or a charged residue to increase their rate of ubiquitination by the ubiquitin ligase E3 $\alpha$ (N-end rule) [16-18]. Another piece of evidence for the involvement of the proteasome in antigen processing came from the observation that proteasome inhibitors blocked the presentation of a number of antigenic peptides while limiting the overall peptide supply to MHC class I [19-27]. Although inhibitors reduced the cell ability to express specific antigenic peptides from full-length proteins, two studies showed that production of the antigenic peptides from minigenes of the correct size was not affected, suggesting that the inhibitors indeed specifically act on the peptide release from the full-length protein $[19,28]$. However, the role of proteasome inhibitors is often hard to interpret, first because inhibitors generally 
induce ER stress, which can affect the rate of synthesis of some proteins [29,30], and second, because they inhibit some catalytic activities of the proteasome, but not others. Their effect may therefore vary according to the main catalytic activity involved in the production of the peptide studied. In addition, the production of a number of peptides depends on a balance between productive cleavages, occurring mostly at the C-terminus, and destructive cleavages occurring within the sequence of the antigenic peptide [31,32]. The net effect of proteasome inhibitors on the production of such peptides therefore depends on the relative inhibition of the catalytic activities responsible for the productive versus destructive cleavages [33]. Studies on the presentation of constructs involving antigenic peptides extended at the $\mathrm{C}$-terminus or the $\mathrm{N}$-terminus indicated that the proteasome was usually required to produce the $\mathrm{C}$-terminal cleavage, but was dispensable for the $\mathrm{N}$-terminal cleavage $[28,34]$. Subsequent studies showed that $\mathrm{N}$-terminally extended peptide precursors produced by the proteasome can be further trimmed by other peptidases, either in the cytosol by tripeptidyl peptidase II (TPPII) [35] or, more prominently, in the ER by the endoplasmic reticulum aminopeptidase ERAP1 [36,37]. Another strong argument for the role of the proteasome in the production of class I peptides lies in the observation that many antigenic peptides are differentially processed by the various proteasomes subtypes, as we will discuss below (Table 1) [31,32,38].

Although the proteasome is considered as the main source of antigenic peptides, it is now clear that it is not the only protease able to generate antigenic peptides [27,39]. Several alternative cytosolic proteases were shown to process specific antigenic peptides, including tripeptidyl peptidase II (TPPII) and the metallopeptidases thimet oligopeptidase, nardilysin and insulin degrading enzyme (IDE) [40-44]. However, the function of these proteases in general MHC class I presentation appears quite limited [45-47]. Additionally, antigenic peptides can also be produced by proteases present in the ER or in the secretory compartment. For example, signal peptidase and/or signal peptide peptidase are both involved in the production of TAP-independent peptides derived from signal sequences [48,49]. Moreover, in cells with a defect in peptide loading complex quality control, trans-Golgi proteases, such as protease pro-protein convertase 7, can rescue a significant proportion of the unstable MHC class I peptides, potentially by making peptides available from full-length proteins [50]. Coupling a murine cytomegalovirus (CMV) epitope to the C-terminus of the secretory hepatitis B protein, HBe, Gil-Torregrosa et al. showed that the trans-Golgi resident protease, furin, which is involved in HBe maturation along the secretory route, helped with releasing the CMV peptide for loading onto $\mathrm{H}-2 \mathrm{~L}^{\mathrm{d}}$ in TAP-deficient cells [51]. Finally, another alternative pathway involved in the presentation of MHC class I-restricted peptides is autophagy, a process that enables non-proteasomal degradation of proteins at steady-state and in conditions of stress, such as starvation or oxidative damage. In the MHC class I pathway, autophagy appears to contribute to the processing of a growing number of antigenic peptides presented by MHC class I and derived from endogenously expressed proteins [52-54]. In the autophagy-based MHC class I processing, cellular proteins are brought to the autophagosome/lysosomal compartment for degradation, and the peptides released are then loaded onto local MHC class I. This process is TAP-independent and gives rise to peptides that can be similar to those produced through the classical proteasome processing pathway [52-54]. Although the relative importance of autophagy in antigen processing still needs to be evaluated further, this process may be important to circumvent viral or tumoral evasion strategies affecting TAP transport. In this review, we will recapitulate the role played by the proteasome and its regulators in the processing of antigenic peptides. 
Table 1. Processing efficiency of tumor antigens by the different proteasome types.

\begin{tabular}{|c|c|c|c|c|c|c|c|}
\hline Peptide source & $\begin{array}{c}\text { MHC } \\
\text { restriction }\end{array}$ & Peptide Sequence & $\begin{array}{c}\text { Standard } \\
\text { Proteasome }\end{array}$ & $\begin{array}{c}\text { Immuno- } \\
\text { proteasome }\end{array}$ & $\begin{array}{c}\text { Intermediate } \\
\text { Proteasome } \\
\beta 5 \mathrm{i} \\
\end{array}$ & $\begin{array}{c}\text { Intermediate } \\
\text { Proteasome } \\
\beta 1 \mathbf{i}-\boldsymbol{\beta 5 i} \\
\end{array}$ & References \\
\hline \multicolumn{8}{|l|}{ Self } \\
\hline $\mathrm{RU}_{34-42}$ & HLA-B51 & VPYGSFKHV & $++\S$ & $+/-$ & n.d. & n.d. & {$[20,31]$} \\
\hline FGF- $5_{172-176 \text { and } 217-220} *$ & HLA-A3 & NTYAS_PRFK & ++ & - & n.d. & n.d. & {$[55,56]$} \\
\hline \multicolumn{8}{|l|}{ Differentiation } \\
\hline gp100 $40-42$ and $47-52 *$ & HLA-A32 & RTK_QLYPEW & ++ & $+/-$ & n.d. & n.d. & {$[22,56]$} \\
\hline gp100 $209-217$ & HLA-A2 & ITDQVPFSV & ++ & $+/-$ & $+/-$ & $+/-$ & {$[12,31,38]$} \\
\hline gp100 $195-202$ and 191 or $192 *$ & HLA-A3 & RSYVPLAH_R & ++ & n.d. & n.d. & n.d. & {$[57]$} \\
\hline Tyrosinase $369-377$ & HLA-A2 & YMDGTMSQ̄V & ++ & $+/-$ & - & $+/-$ & {$[31,38,58]$} \\
\hline Tyrosinase $_{368-373}$ and $336-340 *$ & HLA-A24 & IYMDGT_ADFSF & ++ & - & n.d. & n.d. & [59] \\
\hline Melan- $\mathrm{A}_{26-35}$ & HLA-A2 & EAAGIḠ'ILTV & ++ & - & $+/-$ & $+/-$ & {$[38,60]$} \\
\hline \multicolumn{8}{|l|}{ Cancer germline } \\
\hline MAGE-A3 ${ }_{114-122}$ & HLA-B40 & AELVHFLLL & - & ++ & ++ & ++ & {$[31,38,61]$} \\
\hline MAGE-A3 $271-279$ & HLA-A2 & FLWGPRALV & - & - & ++ & - & {$[32,62]$} \\
\hline MAGE-A10 $254-262$ & HLA-A2 & GLYDGMEHL & - & - & - & ++ & {$[32,63]$} \\
\hline MAGE-C2 $2336-344$ & HLA-A2 & ALKDVEERV & - & ++ & - & ++ & {$[31,38,64]$} \\
\hline MAGE-C2 $42-50$ & HLA-B57 & ASSTLYLVF & - & ++ & ++ & ++ & {$[38,65]$} \\
\hline MAGE-C2 ${ }_{191-200}$ & HLA-A2 & LLFGLALIEV & - & - & - & ++ & {$[38,64]$} \\
\hline \multicolumn{8}{|l|}{ Mutation } \\
\hline $\mathrm{CLPP}_{240-248}$ & HLA-A2 & ILDKVLVHL & $+/-$ & ++ & n.d. & n.d. & [66] \\
\hline HAUS3 $_{154-162}$ & HLA-A2 & ILNAMIAKI & - & n.d. & n.d. & ++ & [67] \\
\hline \multicolumn{8}{|l|}{ Polymorphism (mHC $\left.{ }^{\|}\right)$} \\
\hline SP110 $296-301$ and $286-289 *$ & HLA-A3 & SLPRGT_STPK & $+/-$ & ++ & n.d. & n.d. & {$[56,68]$} \\
\hline
\end{tabular}

* Spliced peptide. ${ }^{\S}++$, efficiently produced; +/-, slightly produced; -, not produced; n.d., not determined. ${ }^{\|} \mathrm{mHC}$, minor histocompatibility antigen. 


\section{The 20S Proteasome}

The 20S proteasome is a cylindric particle of about $700 \mathrm{kDa}$, which is composed of four stacked heptameric rings, each comprising seven subunits. The two outer rings are identical and made of structural $\alpha$ subunits, and the two inner rings each contain seven $\beta$ subunits, three of which mediate the catalytic activity of the proteasome: $\beta 1, \beta 2$ and $\beta 5$ (Figure 1A). Mutagenesis studies and the analysis of the crystal structure of proteasomes complexed with inhibitors showed that peptide bond hydrolysis is mediated by the N-terminal threonine of the catalytically-active $\beta$ subunits, which is exposed to the luminal side of the proteasome particle, in the catalytic chamber [69-72]. The hydroxyl group of the side chain of this threonine produces a nucleophilic attack on the carbonyl of the peptide bond, leading to the formation of an acyl-enzyme intermediate in which a peptide fragment remains attached to the proteasome by an ester link. Water molecules present in the chamber rapidly hydrolyze this acyl-enzyme intermediate, releasing a peptide fragment that is then transferred back into the cytosol [73]. A few years ago, we found that the proteasome was also able to produce antigenic peptides by creating a peptide bond between peptide fragments originally distant in the parental protein [22]. So far, five antigenic peptides were shown to be produced by this new function of the proteasome, called peptide splicing (Table 1) $[22,55,57,59,68,74]$. We showed that peptide splicing takes place in the proteasome chamber, through a process of transpeptidation that involves the nucleophilic attack of the acyl-enzyme intermediate by the N-terminus of a peptide fragment present in the catalytic chamber (Figure 2) [22]. Interestingly, among the five spliced peptides identified to date, three were composed of two non-contiguous peptide fragments spliced together in the reverse order to that in which they occur in the parental protein $[57,59,68]$. Given their nature, spliced antigenic peptides therefore appear as byproducts of the normal proteasome degradation activity. This process leads to the production of a large variety of peptides, as peptide splicing could theoretically involve any peptide fragment released by proteolysis, provided that the nucleophile peptide contains at least three amino acids [57]. Studying the peptide RSYVPLAH_R (splicing of fragment RSYVPLAH with a single arginine) derived from gp100 and presented by HLA-A3, we showed that this minimal size requirement for the nucleophile peptide resulted in the production of a spliced peptide bearing an extended C-terminus, which is then further trimmed by the proteasome in order to produce the final antigenic peptide (Figure 2) [57]. Recently, Mishto et al. suggested the existence of an additional pocket that would accommodate the nucleophile peptide and would be distinct from the primed substrate binding site, which accommodates the part of the peptide substrate located C-terminally from the cleavage site [75]. They suggested that this additional pocket might already be occupied by the splice reactant prior to the formation of the acyl-enzyme intermediate, thereby facilitating and speeding up the splicing reaction. This suggestion arose from their observation that the hierarchy of splicing at various sites within a given peptide did not strictly follow the hierarchy of cleavage at those sites, suggesting additional constraints determining splicing efficiency, such as the affinity of the nucleophile peptide for this postulated pocket. 
Figure 1. Proteasome subtypes and regulators. (A) Mammalian proteasomes are composed of a $20 \mathrm{~S}$ core particle, made of four stacked rings of seven subunits each. The two outer rings are made of $\alpha$ subunits, and the two inner rings are made of $\beta$ subunits, three of which $(\beta 1, \beta 2, \beta 5)$ are catalytically active. Upon induction with IFN $\gamma$ or in immune cells, these catalytic subunits are replaced with their inducible counterparts, $\beta 1 \mathrm{i}, \beta 2 \mathrm{i}, \beta 5 \mathrm{i}$, to form immunoproteasomes. Besides standard and immunoproteasomes, two additional forms of proteasome exist, which contain a mixture of standard and immune catalytic subunits, as indicated. The thymic cortex expresses a specific catalytic subunit, called $\beta 5 \mathrm{t}$, which combines with $\beta 1 \mathrm{i}$ and $\beta 2 \mathrm{i}$ to form the thymoproteasome. The percentage of each proteasome type as measured by a sandwich ELISA approach [32] is indicated for different tissue and tumor types. Thymoproteasome is specifically expressed in cortical epithelial cells (cortical thymic epithelial cells (cTEC)). (B) The two $\alpha$-rings of the $20 \mathrm{~S}$ proteasome interact with regulatory particles of four different types: PA700 (19S), PA28 $\alpha \beta$, PA28 $\gamma$ and PA200. These regulatory particles can bind to one or both sides of the $20 \mathrm{~S}$ particle or form hybrid proteasomes where the $20 \mathrm{~S}$ core binds two different regulators. Representative examples are shown. NT, not tested.

\section{A. 20S Proteasome subtypes}

Standard proteasome

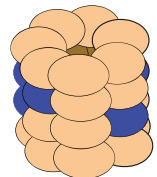

$\beta 1-\beta 2-\beta 5$

Normal Tissues

Liver $(n=3)$

Kidney (cortex)(n=1)

Small Bowel (mucosa) $(n=1)$

Colon (mucosa) $(n=2)$

Heart $(n=3)$

Cortical thymic epithelial cells

Tumors

Melanoma ( $n=4) \quad 88( \pm 3) \%$

Nonsmall cell lung carcinoma $(n=1) \quad 80 \%$

Myeloma $(n=1)$

Antigen Presenting Cells

Monocyte $(n=1)$

$\begin{array}{ll}\text { Mature Dendritic cells }(n=3) & 4( \pm 4) \% \\ & 4( \pm 1) \%\end{array}$

B. Proteasome regulators

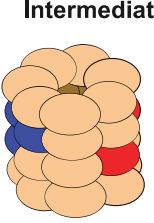

$\beta 1-\beta 2-\beta 5 i$

$50( \pm 8) \%$

$30 \%$

$15 \%$

$49( \pm 10) \%$

$2( \pm 4) \%$
NT

$8( \pm 2) \%$
$0 \%$

$5 \%$

$0 \%$

$42( \pm 5) \%$

$39( \pm 23) \%$

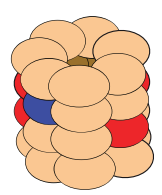

$\beta 1 \mathrm{i}-\beta 2-\beta 5 \mathrm{i}$

$4( \pm 6) \%$
$0 \%$

$21 \%$

$0 \%$

$3( \pm 5) \%$

$4( \pm 3) \%$

$20 \%$

$23 \%$

$54 \%$

$24( \pm 12) \%$

$10( \pm 17) \%$
Immunoproteasome

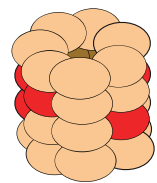

$\beta 1 \mathrm{i}-\beta 2 \mathrm{i}-\beta 5 \mathrm{i}$

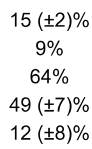

$12( \pm 8) \%$

NT

$0 \%$

$0 \%$
$<2,5 \%$

$31 \%$

$29( \pm 19) \%$

$47( \pm 4) \%$
Thymoproteasome

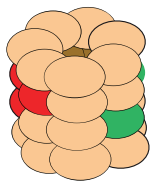

$\beta 1 \mathrm{i}-\beta 2 \mathrm{i}-\beta 5 \mathrm{t}$

$N T$
$N T$
$N T$
$N T$
$N T$
+

$N T$
$N T$
$N T$

$N T$
$N T$
$N T$
$N T$

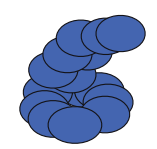

$19 S$

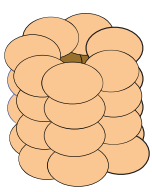

Free 20S

proteasome

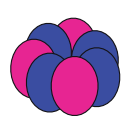

PA28 $\alpha \beta$

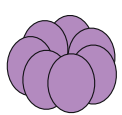

PA28 $\gamma$

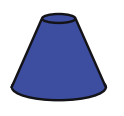

PA200

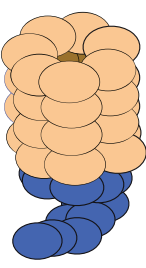

Singly capped proteasome

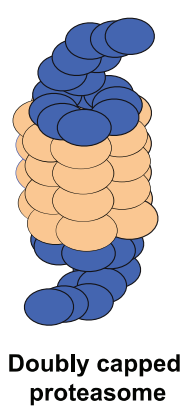

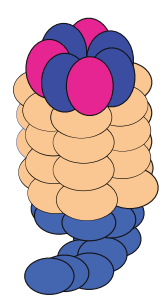

Hybrid proteasome 
Figure 2. Peptide splicing and trimming of the antigenic peptide RSYVPLAH_R derived from gp100 by the proteasome. In the course of peptide-bond hydrolysis, the hydroxyl group of the N-terminal threonine produces a nucleophile attack on the carbonyl of the peptide bond. This leads to the formation of an acyl-enzyme intermediate in which the peptide fragment RSYVPLAH remains attached to the proteasome through an ester link. Normally, this acyl-enzyme intermediate is rapidly hydrolyzed. However, peptide fragments, such as RGS, present in the chamber can compete with water molecules, their free $\mathrm{N}$-terminal amino-group performing a nucleophilic attack on the acyl-enzyme intermediate. This transpeptidation leads to the creation of a new peptide bond, which assembles both fragments, leading to the formation of a spliced peptide bearing an extended C-terminus. The $\mathrm{C}$-terminal extension is then further trimmed by the proteasome to release the antigenic peptide, RSYVPLAHR. Balls represent the catalytic $\beta$ subunits of the proteasome. The hydroxyl group of the $\mathrm{N}$-terminal threonine is indicated.

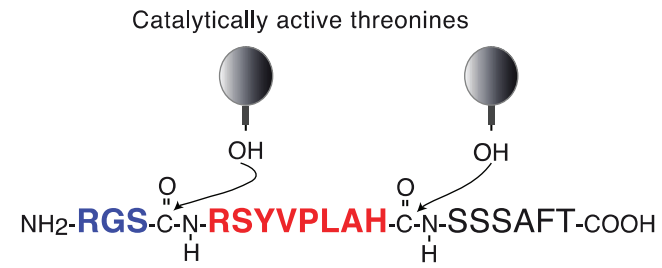

Formation of the acyl-enzyme intermediate

凡
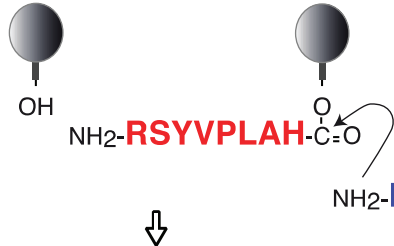

$\mathrm{NH}_{2}$ - SSSAFT-COOH

Transpeptidation

§

$\mathrm{NH}_{2}-\mathrm{RGS}-\mathrm{COOH}$
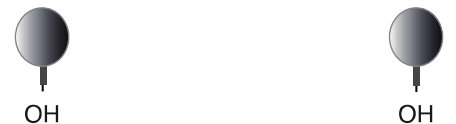

$\mathrm{NH}_{2}$-RSYVPLAH-C̈-N- $\stackrel{\mathrm{O}}{\mathrm{H}}$-RGS- $\mathrm{COOH}$

Formation of the

acyl-enzyme intermediate

Љ

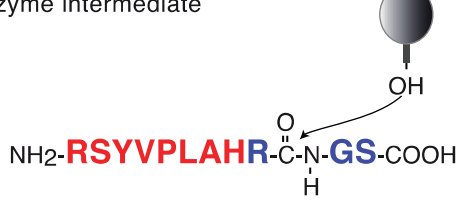

Hydrolysis

ภ

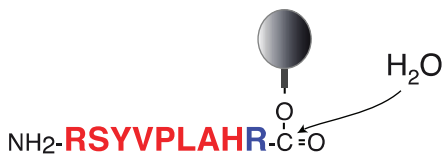

Release of the peptide

Splicing

Trimming 
So far, the identification of spliced antigenic peptides has been limited by the availability of specific CTL directed against these peptides. Using a specific computer-based algorithm applied to the mass spectrometry analysis of peptide digests, Liepe at al. developed a novel approach (SpliceMet) to predict spliced antigenic peptides [76]. One could verify the relevance of these peptides by isolating CTL in vitro using the reverse immunology approach [77]. The presence of the predicted peptide at the surface of target cells would then be confirmed by analyzing the ability of these cells to activate the corresponding CTL.

In essence, the proteolytic activity of the proteasome is not specific: any protein or peptide entering the proteasome can be degraded. It is therefore essential for cellular homeostasis to tightly control the activity of such an abundant intracellular protease, so as to prevent undesired degradation of intracellular proteins. The proteasome therefore evolved as a compartmentalized particle delineating a chamber that is not accessible to surrounding proteins and that contains the catalytically active sites [78]. This enables the control of proteasome activity at the level of the entry of substrates in the catalytic chamber. Indeed, regulators of proteasome activity, such as the 19S regulator, function as gate-keepers, allowing entry into the proteasome particle of only those substrates that need to be degraded and preventing entry of others. Entrance to the chamber is first limited by an aperture consisting of a $13-\AA$ pore delimited by the ring formed by the $\alpha$ subunits, as observed in the Thermoplasma proteasome [69]. The small size of this $\alpha$-annulus ensures that only unfolded proteins can enter the catalytic chamber. Additionally, the entrance of the chamber is further obstructed in yeast and bovine proteasome by the N-terminal tails of the $\alpha$ subunits that form a tight polypeptide net, which is projected inside the pore and prevents access of smaller substrates to the catalytic chamber [70,79]. Free 20S proteasome therefore has a low activity, at least toward folded protein substrates [2]. Opening of the $\alpha$-gate is tightly regulated through the binding of specific activator complexes, called regulatory particles, which are believed to interact with the N-terminal tails of the $\alpha$-subunits, inducing their displacement and the opening of the gate [2]. Four types of regulators exist: the $19 \mathrm{~S}$ regulator (PA700), the $11 \mathrm{~S}$ regulators, PA28 $\alpha \beta$ and PA28 $\gamma$, and the PA200 regulator, whose functions will be discussed below.

As an exception to this rule of access-control by regulators, it has been shown that unfolded protein substrates and oxidant-damaged proteins can be degraded by free $20 \mathrm{~S}$ proteasomes [80,81]. A large excess of enzymatically-active, free 20S proteasome over $26 \mathrm{~S}$ proteasome is indeed found within cells $[82,83]$. A recent study from Baugh et al. suggested that about $20 \%$ of total cellular proteins can be degraded by the $20 \mathrm{~S}$ proteasome [84]. However, how unstructured proteins or oxidant-damaged proteins enter the catalytic core of the $20 \mathrm{~S}$ chamber is still not well understood. Various studies suggested that access to the catalytic chamber could be controlled by the substrate itself or facilitated by accessory proteins, such as Hsp90 [85] or arginine-rich histones [86]. It has been suggested that hydrophobic patches that are often exposed after protein oxidation might facilitate the entry of oxidized proteins into the catalytic chamber [80], in line with the fact that hydrophobic peptides appear to promote the opening of the $\alpha$-ring of the $20 \mathrm{~S}$ proteasome [87]. Conditions of stress, such as oxidative damage or prolonged starvation, induce $26 \mathrm{~S}$ proteasomes to dissociate into $20 \mathrm{~S}$ proteasomes and 19S sub-complexes [88-90]. This leads to a rapid decrease in proteolysis and an accumulation of ubiquitinated proteins, but could favor the degradation of poorly-structured or oxidized proteins by $20 \mathrm{~S}$ proteasomes [88,91]. Reports have suggested that PA28 $\alpha \beta$ could also assist the 20S proteasome in the degradation of oxidized proteins [81,92]. 


\section{Regulation of the Proteasome Activity}

The first level of regulation is achieved by changes in the structure of the 20S proteasome, which exists in several isoforms or subtypes, having different catalytic activities.

\subsection{Proteasome Subtypes}

\subsubsection{Standard Proteasome and Immunoproteasome}

In immune cells or after exposure to the inflammatory cytokines, IFN- $\gamma$ or TNF- $\alpha$, alternative catalytic subunits, named LMP2 ( $\beta 1 \mathrm{i})$, MECL-1 ( $\beta 2 \mathrm{i})$ and LMP7 ( $\beta 5 \mathrm{i})$, are expressed and incorporated into the proteasome in place of their constitutive counterparts, $\beta 1, \beta 2$ and $\beta 5$, to form another particle called the immunoproteasome (Figure 1A) [93]. Based on the degradation of small fluorogenic peptides, three major catalytic activities of the proteasome were described, the caspase-like, trypsin-like and chymotrypsin-like activities, which cleave after acidic, basic and hydrophobic residues, respectively. The study of yeast proteasome mutants suggested that each of these catalytic activities was associated with one specific catalytic subunit. The caspase-like activity is linked to $\beta 1$, while the trypsin-like and chymotrypsin-like activities are associated with $\beta 2$ and $\beta 5$, respectively [72,94,95]. However, it is now clear that the catalytic specificity is more complex than originally expected, since some proteasome subunits have overlapping specificities [95], and the position of the cleavage site can also be influenced by the surrounding residues $[96,97]$. Nevertheless, the immunoproteasome activity, as measured with fluorogenic peptides, is characterized by a lower caspase-like activity and higher trypsin-like and chymotrypsin-like activities [98,99]. Due to these differences in their catalytic sites, the standard proteasome and the immunoproteasome produce distinct peptide sets, which only partly overlap [97,98,100,101]. Because the immunoproteasome shows an increased propensity to cleave after basic or hydrophobic residues, it was predicted to be more efficient at producing antigenic peptides with high affinity for MHC class I molecules, which often call for peptides bearing basic or hydrophobic residues at their C-termini $[98,100]$. This idea was corroborated by the study of knockout mice for either $\beta 1 \mathrm{i}$ or $\beta 5 \mathrm{i}$, in which the presentation of several epitopes was decreased [102,103]. This was recently confirmed using knockout mice for all three immunosubunits, whose dendritic cells fail to present a number of MHC class I epitopes and whose splenocytes display a peptide repertoire that is about $50 \%$ different from that of wild-type cells [104]. In the same line, the peptide repertoire of dendritic cells from $\beta 2 \mathrm{i}^{-/-} \beta 5 \mathrm{i}^{-/-}$mice is less abundant and diverse than that of wild-type mice [105]. Overall, these results show that the immunoproteasome plays an important role in MHC class I antigen presentation. Several human tumor antigens are also better produced by the immunoproteasome than by the standard proteasome (Table 1) $[31,32,38,61,65]$. However, it is also clear that a number of antigenic peptides are better produced by the standard proteasome. The first example of such a peptide was described by Morel et al. who studied a human CTL clone recognizing a peptide derived from ubiquitous protein RU1. This peptide was presented by kidney cancer cells, but not by the autologous EBV-B cells [20]. This was explained by the fact that the peptide was processed efficiently by the standard proteasome, which was present in kidney cancer cells, but not by the immunoproteasome, which was abundant in the EBV-transformed B-cells. Other peptides that are efficiently processed by the standard proteasome, but not by the immunoproteasome, were subsequently identified (Table 1) [31,106]. In vitro digestions 
of peptide precursors with purified proteasomes indicated that the lack of processing by one proteasome type generally resulted from a prominent cleavage within the antigenic peptide, resulting in its destruction [31,32,38]. Similar observations were made when Basler et al. studied the immunoproteasome-dependent generation of the murine minor histocompatibility antigen UTY246-254 and the human influenza matrix peptide58-66 [107]. The authors showed that inhibition of the $\beta 1$ or the $\beta 5$ subunit, respectively, rescued the presentation of these peptides, suggesting that the standard subunits were responsible for their degradation.

In the past few years, we and others identified several peptides produced by peptide splicing in the proteasome. As described above, the peptide splicing reaction takes place in the proteasome trough a reaction of transpeptidation involving the nucleophilic attack of an acyl-enzyme intermediate by another peptide fragment present in the chamber [22]. We found that three spliced peptides were better produced by the standard proteasome than by the immunoproteasome, while another was more efficiently produced by the immunoproteasome [56]. This demonstrated that both proteasome types can perform the splicing reaction. However, we observed that the production of a given spliced peptide depended on the ability of the proteasome to perform the cleavages required to liberate the fragments that composed the spliced peptide. Additionally, this ability differed among the two proteasome subtypes. Of note, even though it was initially identified in tumor cells, peptide splicing is not restricted to tumor cells, but can also occur in non-tumor cells, such as melanocytes [59]. In vitro, it was produced using proteasomes originating from human erythrocytes, but also from yeast cells [22,75]. It is therefore expected that peptide splicing also occurs in the thymus, where spliced peptides should be expressed like any other self-peptides to establish natural immune tolerance, on the condition that the type of proteasome (standard or immunoproteasome) present in medullary thymic epithelial cells is adequate for the production of these peptides.

The induction of T-cell immune responses is critically dependent on dendritic cells, which are professional antigen-presenting cells located mostly in lymph nodes. These cells uniquely express the set of cytokines and costimulatory molecules required to activate naive T-cells in an antigen-specific manner. This means that CTL responses will be induced only against antigenic peptides presented by dendritic cells. Dendritic cells contain immunoproteasomes and intermediate proteasomes (see below), but very little standard proteasome (Figure 1A) [32]. Therefore, they will mostly induce CTL responses against peptides produced by the immunoproteasome (or intermediate proteasomes), but not against peptides produced by the standard proteasome. Regarding anti-viral responses, this is not an issue, because viral infections usually trigger inflammation, which induces immunoproteasomes in infected cells, which therefore will present the adequate antigenic peptides. Indeed, immunoproteasome-dependent peptides were shown to be the dominant targets of anti-viral CTL responses [108]. However, in the case of anti-tumor immune responses, the situation is different, because tumor cells usually do not contain immunoproteasomes, unless they are exposed to inflammation, and therefore, they may not present the peptides against which the immune response was triggered by dendritic cells [106]. Moreover, as indicated above, a number of clinically relevant tumor antigens are produced by the standard proteasome, but not by the immunoproteasome, and therefore are not presented efficiently by dendritic cells [20,31]. Vaccination strategies aimed at inducing CTL against such antigens should therefore be adapted in order to by-pass processing by the proteasome of dendritic cells. This can be done by immunizing with short "pre-processed" synthetic peptides or with recombinant minigene constructs encoding only the short 
peptide. This notion was first confirmed by a study comparing the CTL responses induced against the HLA-A2-restricted peptide, melan-A26-35, after vaccination of wild-type and $\beta 1$ i-knock-out HLA-A2 transgenic mice with either the peptide-encoding minigene or the full-length melan-A [109]. Stronger responses were induced in wild-type mice when the immunization was performed using the minigene retroviral construct when compared to the full-length construct, and this difference was reduced in the $\beta 1$-knockout mice, which developed stronger responses to the full-length construct than the wild-type mice. This confirmed that the immunoproteasome was responsible for the poor responses in wild-type mice. Another approach to induce CTL responses against standard proteasome-dependent peptides is to engineer dendritic cells so that they no longer contain immunoproteasomes, but only standard proteasomes. Dannull et al. successfully used this approach in humans, using siRNA for the catalytic immunosubunits. They showed that dendritic cells transfected with those siRNA and with RNA encoding full-length tumor antigens induced better anti-tumor CTL responses, not only in vitro, but also in vivo in melanoma patients [110,111].

As mentioned above, the immunodominance hierarchy of viral antigens is linked to their dependency on processing by the immunoproteasome. Indeed, studying CTL responses against various influenza, MCMV (mouse cytomegalovirus) and LCMV (lymphocytic choriomeningitis virus) peptides, several groups observed changes in the responses to these peptides in knockout mice for some of the immunoproteasome subunits [108,112-115]. Responses to antigenic peptides were generally decreased, but in some cases, responses were improved or remained stable. Interestingly, this ended up modifying the immunodominance hierarchy, with dominant epitopes becoming subdominant, and vice versa [108]. The modification of the responses observed in these different models were generally attributed to a difference in the processing of the antigenic peptide by the proteasome types and/or to an alteration of the T-cell repertoire in immunoproteasome-deficient animals [108,112,114]. This latter point implies that, in immunoproteasome-deficient animals, the negative selection operated in the thymus has led to the deletion of T-cell precursors recognizing those viral epitopes. Negative selection occurs in the thymic medulla, where medullary thymic epithelial cells (mTEC) present MHC class I-restricted peptides derived from a variety of self-proteins. This induces the selective deletion of T-cell precursors reactive to these peptides. The proteasome content of mTEC has not yet been clearly evaluated, but it is thought to mostly correspond to immunoproteasomes. Alteration of the anti-viral repertoire in immunoproteasome subunit-deficient animals therefore suggests that the absence of some immunoproteasome subunits in mTECs enables the expression of novel self-peptides that mimic the viral epitopes and lead to the deletion of the corresponding anti-viral T-cell precursors.

Studying the role of the immunoproteasome in the establishment of a T-cell response to MCMV in wild-type and $\beta 5 \mathrm{i}^{-/-}$mice, Hutchinson et al. observed that although acute responses to MCMV mostly targeted immunoproteasome-dependent peptides, memory responses targeted those two epitopes that showed the least dependency on the immunoproteasome [115]. Acute MCMV T-cell responses would therefore be elicited by cells containing some immunoproteasome. However, this response would not be totally efficient at destroying target cells infected by MCMV, as this virus impedes immunoproteasome formation through the action of M27, a protein that induces the proteasomal degradation of STAT2 and thereby inhibits the IFN $\gamma$ response pathway [116]. Chronic responses to MCMV would then involve antigen-presenting cells containing only standard proteasomes and stimulating CTL against those epitopes that are the least dependent on the immunoproteasome. 


\subsubsection{Intermediate Proteasomes}

Using a unique set of antibodies directed against proteasome catalytic subunits, our group additionally described two alternative proteasome forms, which are intermediate between the standard and the immunoproteasome, and contain only one ( $\beta 5 \mathrm{i})$ or two $(\beta 1 \mathrm{i}, \beta 5 \mathrm{i})$ of the three catalytic subunits of the immunoproteasome (immunosubunits) (Figure 1A) [32]. The existence of intermediate proteasome forms had previously been inferred from the observation that a number of tissues contained only some of the three immunosubunits [117]. It is only the development of immunosubunit-specific antibodies able to capture proteasomes in their native form that allowed us to define the exact stoichiometry of the intermediate proteasomes that are found in human tissues [32]. The existence of only two forms of intermediate proteasomes, namely $\beta 5 \mathrm{i}$ and $\beta 1 \mathrm{i}-\beta 5 \mathrm{i}$, is in agreement with the previous works dissecting the general rules for proteasome cooperative assembly [93,118], which is dependent on the nature of the subunit propeptides $[119,120]$. This cooperative assembly ensures a preferential incorporation of immunosubunits over standard subunits, where, e.g., incorporation of $\beta 2 \mathrm{i}$ is dependent on that of $\beta 1 \mathrm{i}$ [93]. This may explain why we did not detect the presence of intermediate proteasomes containing $\beta 2 \mathrm{i}$. In addition, catalytic subunits are initially incorporated in an immature form, containing an $\mathrm{N}$-terminal peptide that needs to be cleaved to liberate the N-terminal threonine of the mature active site [121]. This maturation step occurs at the last stage of proteasome assembly, when two hemiproteasomes join together to form the final particle. Again, this ensures protection of the cellular proteins, as catalytic sites only become active when the final particle is assembled and confines the proteolytic activity to the inner chamber. Maturation of the immunosubunits is interdependent: $\beta 5 \mathrm{i}$ was shown to be required for the maturation of $\beta 1 \mathrm{i}$ and $\beta 2 \mathrm{i}$ [93]. This may explain why we did not detect intermediate proteasomes lacking $\beta 5 \mathrm{i}$. Because the proteasome particle contains two $\beta$ rings, the existence of proteasomes containing an asymmetric assortment of immunosubunits and standard subunits is conceivable. Such asymmetric proteasomes were observed in cells transfected with a tagged $\beta 1$ and exposed to IFN $\gamma$ [122], but it remains unclear whether they exist in unmanipulated cells or tissues. The intermediate proteasomes we described were symmetric. We searched for asymmetric proteasomes containing $\beta 5$ on one $\beta$ ring and $\beta 5 \mathrm{i}$ on the other, and we did not find any in human liver and melanoma [32].

Interestingly, intermediate proteasomes $\beta 5 \mathrm{i}$ and $\beta 1 \mathrm{i}-\beta 5 \mathrm{i}$ represent $10 \%$ to $20 \%$ of the total proteasomes found in tumors and $30 \%$ to $50 \%$ of those found in liver, kidney, small bowel, colon and dendritic cells [32] (Figure 1A). Studying the specific cleavage properties of each proteasome type, we showed that intermediate proteasomes $\beta 5 \mathrm{i}$ and $\beta 1 \mathrm{i}-\beta 5 \mathrm{i}$ both display trypsin and chymotrypsin-like activities that are intermediate between those of the standard and the immunoproteasome. The caspase-like activity of intermediate proteasome $\beta 5 \mathrm{i}$ is similar to that of the standard proteasome, while this activity is low in intermediate proteasome $\beta 1 \mathrm{i}-\beta 5 \mathrm{i}$. This is easily explained by the fact that the caspase-like activity is generally associated with the $\beta 1$ subunit, which is present in the $\beta 5 \mathrm{i}$ intermediate proteasome and not in the $\beta 1 \mathrm{i}-\beta 5 \mathrm{i}$ intermediate proteasome [32]. Owing to their specific cleavage properties, intermediate proteasomes produce a unique set of antigenic peptides. The HLA-A2-restricted peptides, MAGE-A10254-262 and MAGE-C2191-200, are exclusively produced by the intermediate proteasome, $\beta 1 \mathrm{i}-\beta 5 \mathrm{i}$, while the HLA-A2-restricted peptide, MAGE-A3271-279, is processed only by intermediate proteasome $\beta 5$ i (Table 1) $[32,38]$. Hence, intermediate proteasomes enlarge the MHC class I repertoire to peptides that can be processed by both dendritic cells (containing immunoproteasomes and intermediate 
proteasomes) and tumor cells (containing standard proteasomes and intermediate proteasomes) and might therefore represent valuable targets for cancer immunotherapy. Of note, the presence of intermediate proteasomes should also be taken into account when analyzing the role of the immunoproteasome in single-immunosubunit $\mathrm{KO}$ mice.

\subsubsection{Thymoproteasome}

A few years ago, Murata et al. discovered the existence of an additional proteasome catalytic subunit, called $\beta 5 \mathrm{t}$, which is specifically expressed in the cortical thymic epithelial cells (cTEC) and is homologous to the $\beta 5$ and $\beta 5$ i subunits $[123,124]$. The cTEC are responsible for positive selection, a process by which immature T-cell precursors able to bind to self-MHC class I/peptide complexes on cTEC are triggered to survive. The $\beta 5 \mathrm{t}$ subunit has a dramatic effect on the establishment of the CTL repertoire, as $\beta 5$ t-deficient mice display an $80 \%$ reduction of splenic CTL and do not survive influenza virus infection $[123,125]$. The $\beta 5 \mathrm{t}$ subunit is incorporated in the $20 \mathrm{~S}$ proteasome instead of $\beta 5 \mathrm{i}$ along with $\beta 1 \mathrm{i}$ and $\beta 2 \mathrm{i}$ (Figure 1A) [123]. Incorporation of $\beta 5 \mathrm{t}$ into HEK-293T proteasomes induced a dramatic decrease of the chymotrypsin-like activity when compared to the $\beta 5$-containing proteasome, while the trypsin-like and caspase-like activities were not affected [123]. This is in line with the fact that the $\mathrm{S} 1$ pocket of $\beta 5 \mathrm{t}$ is lined by hydrophilic amino acids, while that of $\beta 5$ or $\beta 5 \mathrm{i}$ contains hydrophobic residues [123]. Using a unique set of antibodies recognizing peptide-bound or empty MHC class I molecules, Nitta et al. showed that cTECs from both wild-type or $\beta 5 \mathrm{t}^{-/-}$mice express MHC class I molecules associated with peptides. Some of these peptides appeared unique to cTECs, as two specific peptide populations bound to $\mathrm{H}-2 \mathrm{~K}^{\mathrm{b}}$ were found to be differentially expressed in cTECs when compared to other APCs [125], suggesting that cTECs display a qualitatively distinct repertoire of MHC class I/peptide complexes. It was originally proposed that the low chymotrypsin-like activity of the thymoproteasome might produce low-affinity MHC class I ligands that may limit the duration or the avidity of the interaction of the peptide/MHC complexes with the TCR and facilitate positive selection $[123,126]$. However, recent work by Xing et al. showed that the half-life of MHC/peptide complexes on the surface cTEC and mTEC was similar, disagreeing with the idea that cTEC would carry unstable MHC complexes responsible for positive selection [127]. Moreover, similar surface MHC class I levels are found in $\beta 5 \mathrm{t}^{+/-}$and $\beta 5 \mathrm{t}^{-/-}$cTECs [123]. To reconcile these observations, it was proposed that cTECs carried peptides binding MHC class I using alternative anchor positions or developed a mechanism enabling them to stabilize MHC class I molecules bearing low affinity peptides [128]. In the future, a more detailed analysis of the peptide repertoire found on cTECs might help to understand the role played by the thymoproteasome in the formation of an immunocompetent $\mathrm{T}$-cell repertoire.

\subsubsection{Proteasome Subtypes and Negative Selection of T-Cell Precursors in the Thymus}

It is interesting to note that, so far, most tumor antigenic peptides found to be poorly processed by the immunoproteasome derive from self-proteins expressed in normal adult tissues (Table 1). Because the thymus contains abundant amounts of immunoproteasome, this precludes the processing of these peptides by the medullary thymic epithelial cells (mTEC), resulting in a lack of negative selection of T-cells recognizing these antigens and explaining why these T-cells persist in the periphery. In contrast, tumor antigens, which are better produced by the immunoproteasome, often correspond to MAGE-type 
antigens encoded by cancer-germline genes or to mutated antigens $[31,32,66]$. The limited immune tolerance against MAGE-type antigens has been attributed to the very low expression of cancer-germline genes in mTEC, resulting in the negative selection of only those T-cells recognizing these antigens with a high avidity [129]. The anti-tumor T-lymphocytes present in the blood of cancer patients would then derive from low-avidity T-cells that escape negative selection in the thymus. To confirm this concept, our group recently produced knockout mice for a mouse cancer-germline gene, namely P1A [130]. The expectation was that these mice, which are devoid of P1A expression in the thymus, should contain an unselected anti-P1A T-cell repertoire still containing high-affinity T-cells. Surprisingly, although the frequency of anti-P1A T-cells was slightly higher in P1A-KO mice, the anti-P1A T-cell repertoire of P1A-KO mice was barely different from that of wild-type mice, indicating that there is only minimal tolerance against this antigen in wild-type mice, despite detectable expression of P1A in mTEC [130]. Further analysis of the processing of the P1A antigen and of the type of proteasome contained in mTEC might help understanding the reason for the lack of tolerance against antigens encoded by cancer-germline genes.

\subsubsection{Structure-Related Properties}

The crystal structures of the mouse standard proteasome and the immunoproteasome were solved recently and revealed that the cleavage preferences of the immunoproteasome relied on subtle conformational changes in the substrate-binding pockets of catalytic subunits $\beta 1 i$ and $\beta 5 i$ [131]. Indeed, the substrate-binding channel of $\beta 1 \mathrm{i}$ is lined with hydrophobic amino acids, resulting in an increased hydrophobicity and a decreased size of the binding pocket, thereby accounting for the higher cleavage activity of $\beta 1 \mathrm{i}$ after small hydrophobic and branched residues [131]. Compared to $\beta 5, \beta 5 \mathrm{i}$ harbors a more spacious S1 pocket, favoring access to large non-polar residues and explaining the higher chymotrypsin-like activity of $\beta 5 \mathrm{i}$ [131]. Additionally, the vicinity of the active site of $\beta 5 \mathrm{i}$ is more hydrophilic: this is predicted to favor proteolysis by attracting water molecules, but also by stabilizing the tetrahedral intermediate through additional hydrogen bonds with the oxyanion hole [131].

Studying the processing of the HLA-A2-restricted peptide, MAGE-A10254-262, we observed that this peptide could only be processed by the intermediate proteasome $\beta 1 \mathrm{i}-\beta 5 \mathrm{i}$ and that the inability of the other proteasomes to produce the peptide was related to the occurrence of a destructive cleavage within the peptide after aspartate257 $\left(\mathrm{D}_{257}\right)$ (Table 1) [32]. The caspase-like activity, which is defined by cleavage after acidic residues, is generally associated with the presence of the $\beta 1$ subunit, and digestion of fluorogenic peptides showed that the intermediate proteasome $\beta 1 \mathrm{i}-\beta 5 \mathrm{i}$ and the immunoproteasome display a much lower caspase-like activity than the standard proteasome. However, in the case of the MAGE-A10254-262 peptide, the immunoproteasome still performed the destructive cleavage after $\mathrm{D}_{257}$, despite the presence of the $\beta 1 \mathrm{i}$ subunit. Therefore, the ability of the intermediate proteasome $\beta 1 \mathrm{i}-\beta 5 \mathrm{i}$, as opposed to the immunoproteasome, to produce the antigenic peptide suggests that $\beta 2 \mathrm{i}$ negatively influences the production of this peptide, either because $\beta 2 \mathrm{i}$ itself displays sufficient caspase-like activity to destroy the peptide or because it affects the structure of the immunoproteasome and increases its ability to cleave after $\mathrm{D}_{257}$. Such an allosteric effect of one subunit on the activity of the others was previously suggested by Sijts et al. who showed that subunit $\beta 5 \mathrm{i}$, by impacting the structure of the $20 \mathrm{~S}$ proteasome, increases the activity of subunits $\beta 2 \mathrm{i}$ and $\beta 1 \mathrm{i}[132]$. 


\subsubsection{Other Functions of the Immunoproteasome}

It is quite likely that the function of the different proteasome types is not restricted to antigen processing. The work of Seifert et al., for example, suggested a role for the immunoproteasome in the degradation of polyubiquitinated, oxidant-damaged proteins accumulating after IFN $\gamma$ treatment [133]. However, the prominent role of the immunoproteasome in the degradation of polyubiquitinated proteins was not confirmed by others [134]. Another role for the immunoproteasome was suggested by the observation that the absence of $\beta 1 \mathrm{i}$ in NOD mice impaired the processing of the NF- $\kappa \mathrm{B}$ p105-p50 [135]. However, this study was refuted early after publication, and the function of the immunoproteasome in the NF- $\mathrm{kB}$ signaling pathway has remained largely debated since then [136-140]. Interestingly, the use of the $\beta 5 \mathrm{i}$-specific inhibitor, PR-957, affected the production of inflammatory cytokines IL-23, TNF- $\alpha$ and IL- 6 by endotoxin-stimulated peripheral blood mononuclear cells in an NF- $\kappa$ B-independent manner [141]. The inhibitor also affected the production of IFN $\gamma$ and IL-2 in stimulated T-cells and helped with controlling the pathogenic response in a mouse model of rheumatoid arthritis [141].

\subsection{Proteasome Regulators}

As mentioned above, a key step in the control of proteasome activity is exerted at the level of substrate entry into the catalytic chamber of the particle and depends on the presence of regulators.

\subsubsection{The 19S Regulator}

The 19S regulator (PA700) is a large particle of about $700 \mathrm{kDa}$ that associates with one or both sides of the $20 \mathrm{~S}$ proteasome core to enable the proteasome to bind, deubiquitylate, unfold and translocate the protein substrate into the catalytic chamber. The 19S regulator specifically recognizes proteins targeted for degradation by the covalent attachment of ubiquitin molecules (74 amino acids in length) to lysine residues within protein substrates. The ubiquitination requires the sequential action of an ubiquitin-activating enzyme, E1, an ubiquitin-conjugating enzyme, E2, and an ubiquitin-ligase enzyme, E3 (reviewed in [142]). Additional ubiquitin molecules can then be ligated to a previously bound ubiquitin to form polyubiquitin chains. Chains of four or more ubiquitins are sufficient to target proteins for degradation.

The 19S regulator is composed of at least 19 subunits that are assembled in two different parts: the lid and the base (reviewed in [2]). In yeast, the base comprises six ATPases (Rpt1-6), the two large non-ATPase subunits, Rpn1 and Rpn2, and two ubiquitin receptor subunits, Rpn10 and Rpn13. The six AAA-ATPase subunits, Rpt1-6, form a heterohexameric ring that directly contacts the $\alpha$ ring of the core $20 \mathrm{~S}$ particle and is responsible for the ATP-dependent unfolding and translocation of the substrate into the chamber. The Rpn10 and Rpn13 subunits directly bind the polyubiquitin chains of protein substrates. The lid comprises nine Rpn subunits (Rpn3, 5-9, 11, 12 and 15). Subunits Rpn3, $5,6,7,9,12$ have very similar domain structures and comprise an N-terminal helix repeat segment, a proteasome-COP9/signalosome-eIF3 (PCI) domain and a long C-terminal helix [143]. The Rpn8 and 11 subunits contain an Mpr1-Pad1-N-terminal (MPN) domain, and Rpn11 bears a deubiquitylation activity (DUB) $[144,145]$. The role of the other PCI and MPN subunits has not yet been characterized, except for Rpn6, whose crystal structure suggested a critical role in stabilizing the interaction between 
the 20S core particle and the regulatory complex [146]. The 19S regulator can associate with one or both ends of the 20S proteasome particle, but can also be part of a hybrid proteasome composed of one 19S regulator and one PA28 or PA200 regulator bound to either end of the 20S proteasome complex (Figure 1B) [147,148].

\subsubsection{The PA28 $\alpha \beta$ Regulator}

The PA28 $\alpha \beta$ regulator (11S regulator) was originally isolated owing to its ability to stimulate the hydrolysis by the $20 \mathrm{~S}$ proteasome of small peptide substrates, but not intact, folded proteins [149-151]. It is composed of two subunits, $\alpha$ and $\beta$, whose transcription is induced following exposure to IFN $\gamma[152,153]$. Electron-microscopic studies showed that the PA28 $\alpha \beta$ subunits assemble to form a ring-shaped heptameric complex with a $3 \alpha 4 \beta$ conformation that interacts with the $\alpha$-ring of the $20 \mathrm{~S}$ proteasome complex [154-156]. The PA28 $\alpha \beta$ complex binds either to both ends of the $20 \mathrm{~S}$ proteasome or to only one side of the particle, which binds a $19 \mathrm{~S}$ regulator on the other side to form the so-called hybrid proteasome (Figure 1B) [147,157,158]. A number of mechanisms have been proposed to explain how PA28 $\alpha \beta$ increases proteasome activity, including the allosteric activation of the active sites of the proteasome [149] and the stimulation of peptide entry [159] or exit [160,161] from the 20S chamber. Other explanations include the coupling of the proteasome to chaperones that facilitate substrate delivery inside the catalytic chamber or the interaction of PA28-containing proteasomes with ER membranes to facilitate the transfer of the produced peptides into the ER lumen [151,162]. Studying antigen presentation in mice deficient for PA28 $\beta$, Preckel et al. showed that these mice, which lack both PA28 $\alpha$ and PA28 $\beta$, were impaired in their ability to process antigens [163]. In addition, these PA28-deficient cells displayed a dramatic decrease in immunoproteasome content, which, together with the fact that PA28 was found to be associated with immunosubunit-containing hemiproteasomes, led the authors to conclude that PA28 $\alpha \beta$ was necessary for immunoproteasome assembly [163]. Yet, in subsequent studies using PA28 $\alpha$ and PA28 $\beta$ double-knockout mice, Murata et al. observed normal immunoproteasome assembly and normal immunity to influenza infection [164]. In this study, however, the authors observed that PA28 $\alpha \beta^{-/-}$cells were unable to process a peptide derived from the murine melanoma differentiation antigen, TRP2 (TRP2181-188). Overall, the authors concluded that PA28 was not required for proteasome assembly nor overall MHC class I presentation, but was, rather, involved in the processing of a subset of antigenic peptides [164]. Later on, several in vitro and in vivo studies highlighted a role for PA28 $\alpha \beta$ in the processing of other MHC class I peptides (Table 2). In vitro digestions of precursor peptides by $20 \mathrm{~S}$ proteasomes in the presence or absence of recombinant PA28 $\alpha \beta$ showed that PA28 $\alpha \beta$ increases cleavage efficiency and the production of MHC ligands by the proteasome [165,166]. Association of the proteasome with PA28 also favors double cleavages, which was assumed to originate from the retention by PA28 of the peptide substrate inside the proteasome chamber, thereby increasing the probability for a second cleavage to occur [165]. Transfecting PA28 $\alpha \beta$ into mouse fibroblasts expressing the murine cytomegalovirus antigen pp89, Groettrup et al. observed a marked increase in recognition by the virus-specific cytotoxic T-cells [167]. In this system, presentation of the influenza nucleoprotein was also significantly improved. Later on, the same authors showed that the increase in antigen presentation of the pp89 peptide was independent of the proteasome-subunit composition and therefore, rather, resulted from the general ability of PA28 to activate proteasome complexes without affecting 
proteasome-subunit composition [168]. Overexpression of PA28 $\alpha \beta$ also increased the presentation of a number of viral epitopes, while it did not affect the production of others $[169,170]$. Studying the role of PA28 $\alpha \beta$ on the processing of the peptide TRP2 $360-368$ derived from the human melanoma differentiation antigen, TRP2 [171], Sun et al. observed that this peptide was not processed in a melanoma cell line lacking PA28, but this processing was rescued after transient transfection of PA28 cDNAs. Interestingly, the replacement of the flanking sequences of a PA28-independent antigenic peptide by those of the PA28-dependent peptide TRP2360-368, revealed that the terminal flanking sequence of the peptide TRP2360-368 was sufficient to confer PA28 $\alpha \beta$ dependency [172]. The origin of this sequence-driven dependency has not yet been clarified. Lastly, an allele-specific involvement of PA28 $\alpha \beta$ was observed, as it reduced the processing of $\mathrm{K}^{\mathrm{d}}$ and $\mathrm{D}^{\mathrm{d}}$ ligands, while favoring the presentation of $\mathrm{K}^{\mathrm{b}}$ and $\mathrm{L}^{\mathrm{d}}$ peptides [173]. Overall, PA28 $\alpha \beta$ appears not to be essential for the MHC class I processing pathway, but rather to be involved in the presentation of a selective set of antigenic peptides.

Table 2. The effect on the proteasome regulator PA28 $\alpha \beta$ on the processing of viral and tumor antigens. LCMV, lymphocytic choriomeningitis virus.

\begin{tabular}{|c|c|c|c|c|}
\hline Peptide Source & $\begin{array}{c}\text { MHC } \\
\text { Restriction } \\
\end{array}$ & $\begin{array}{c}\text { Peptide } \\
\text { Sequence }\end{array}$ & $\begin{array}{c}\text { Dependence on } \\
\text { PA28 } \alpha \beta \\
\end{array}$ & References \\
\hline \multicolumn{5}{|l|}{ Viral antigens } \\
\hline $\begin{array}{l}\text { Murine cytomegalovirus } \\
\text { pp89 }\end{array}$ & $\mathrm{H}-2 \mathrm{~L}^{\mathrm{d}}$ & YPHFMPTNL & + & {$[167,168]$} \\
\hline $\begin{array}{l}\text { Murine Moloney MuLV } \\
\quad \text { Gag-leader } 75-83\end{array}$ & $H-2 D^{b}$ & CCLCLTVFL & + & [169] \\
\hline $\begin{array}{l}\text { Murine Moloney MuLV } \\
\text { gp75-env } \\
189-196\end{array}$ & $\mathrm{H}-2 \mathrm{~K}^{\mathrm{b}}$ & SSWDFITV & - & [169] \\
\hline LCMV nuceoprotein $_{118-126}$ & $\mathrm{H}-2 \mathrm{~L}^{\mathrm{d}}$ & RPQASGVYM & - & [174] \\
\hline JAK1 tyrosine kinase $355-363$ & $\mathrm{H}-2 \mathrm{~K}^{\mathrm{d}}$ & SYFPEITHI & + & {$[165]$} \\
\hline $\begin{array}{c}\text { Influenza A/PR/8 } \\
\text { nucleoprotein }_{146-154}\end{array}$ & $\mathrm{H}-2 \mathrm{~K}^{\mathrm{d}}$ & TYQRTRALV & + & [167] \\
\hline \multicolumn{5}{|l|}{ Murine tumor Antigens } \\
\hline TRP $2_{181-188}$ & $\mathrm{H}-2 \mathrm{~K}^{\mathrm{b}}$ & VYDFFVWL & + & [164] \\
\hline \multicolumn{5}{|l|}{ Human Tumor Antigen } \\
\hline $\mathrm{TRP} 2_{360-368}$ & HLA-A2 & TLDSQVMSL & + & {$[171,172]$} \\
\hline TRP $2_{288-296}$ & HLA-A2 & SLDDYNHLV & - & {$[172]$} \\
\hline
\end{tabular}

\subsubsection{The PA28 $\gamma$}

PA28 $\gamma$ was first identified as the $K i$ antigen, target of autoantibodies in the sera of patients with systemic lupus erythematosus [175]. In contrast to PA28 $\alpha \beta$, PA28 $\gamma$ is not induced by IFN $\gamma$ and has a predominant localization in the nucleus [151], where it binds and activates the 20S proteasome as an active homoheptamer [176]. PA28 $\gamma$-deficient mice display reduced body size and defects in cell proliferation [177,178]. PA28 $\gamma$-deficient embryonic fibroblasts show defects in mitotic progression and increased apoptosis, suggesting that the regulator is involved in cell cycle progression and apoptosis [177,178]. Accordingly, several binding partners of PA28 $\gamma$ were identified, whose functions are related to apoptosis, such as caspase-7 and MEKK3 $[179,180]$. Moreover, PA28 $\gamma$ was shown to be 
involved in the ubiquitin- and ATP-independent degradation of a number of cell-cycle regulatory proteins, such as the cyclin-dependent inhibitor p21, or the steroid receptor coactivator 3 (SRC-3), which is an oncogene often amplified in breast cancer and involved in cell growth $[181,182]$. Recent studies have also shown that PA28 $\gamma$ is involved in DNA repair and chromosome stability and takes part in the organization of the nuclear speckle and the trafficking of SR proteins (proteins with long serine and arginine repeats, involved in RNA splicing) to the transcription sites [183-185]. Interestingly, PA28 $\gamma$ was shown to inhibit the activity of p53, a central transcription factor involved in cell cycle arrest and apoptosis, by inducing p53 nuclear export and promoting its MDM2-dependent ubiquitination and proteasome degradation [186,187]. The role of PA28 $\gamma$ in the stability of p53 was recently shown to originate from the PA28y-dependent degradation of casein kinase 1 (CK1), which negatively regulates MDM-2 [188]. Additionally, a negative feedback loop between p53 and PA28 $\gamma$ helps with maintaining the balance of p53 and PA28 $\gamma$ in cells [189].

Contrary to PA28 $\alpha \beta$, which improves all three catalytic activities of the proteasome; PA28 $\gamma$ was shown to selectively activate the trypsin-like activity without affecting the chymotrypsin-like and the caspase-like activities [190]. However, the role of PA28 $\gamma$ in antigen processing appears relatively insignificant, as PA28 $\gamma$-deficient mice display normal levels of MHC class I molecules and are not affected in their responses to influenza virus [178]. However, a slower clearance of the intracellular fungal pathogen Histoplasma capsulatum was observed, in parallel with a slight decrease in the number of total CD8 ${ }^{+} \mathrm{T}$-cells in infected animals [178]. The origin of this defect was not identified.

\subsubsection{The PA200 Regulator}

PA200 is a $200 \mathrm{kDa}$ protein originally identified in rabbit reticulocyte lysate and bovine testis, where it was bound to $20 \mathrm{~S}$ proteasomes $[148,191]$. Similarly to the proteasome regulator, PA28 $\alpha \beta$, PA200 stimulates the proteasome hydrolysis of small peptides, but not folded proteins, and it does so in an ATP-independent manner [148]. Contrary to PA28 $\alpha \beta$, which activates all three proteasome catalytic activities, or to PA28 $\gamma$, which activates only the trypsin-like activity, PA200 was shown to increase the hydrolysis of peptides bearing an acidic residue in P1 (caspase-like activity) [148]. PA200 is particularly abundant in testis, where it might play an important role in the maturation of spermatozoa and in the progression of spermatogenesis. Interestingly, after gamma irradiation, cellular levels of PA200/19S hybrid proteasomes are increased [192], and the complex relocalizes to intranuclear foci [148], where PA200 accumulates on chromatin. This leads to an increase in proteasome-related caspase-like activity at the chromatin site [192]. Interestingly, PA200 knockdown was found to impair cell survival after gamma-irradiation [148], a phenomenon that could be counteracted by the addition of exogenous glutamine. This suggested that PA200-deficient cells are unable to cope with the increased glutamine demand that arises following irradiation. The reason for this is not yet clear, but it was suggested that the caspase-like activity of the PA200-19S hybrid proteasome might help with restoring the intracellular levels of glutamine or glutamate necessary for the long-term survival of tumor cells following radiation exposure [192]. So far, no involvement of PA200 in the production of antigenic peptides has been reported. 


\section{Conclusions}

The proteasome is a major regulator of protein homeostasis in cells. Through its function in protein degradation, the proteasome enables the cell to adapt to the various assaults and changes occurring in its environment. For each situation, a specific proteasome regulator is involved, granting access to protein substrates into the chamber. Proteasome activity is also regulated by its composition in catalytic subunits, which modulates the cleavage specificities of the particle. As a result of its protease activity, the proteasome releases small peptides that can be loaded onto MHC class I molecules and transported to the cell surface for recognition by the immune system. Proteasome regulation is an important parameter determining the type of peptides presented at the cell surface and thereby affecting the ability of the immune system to respond to the presence of viruses and tumor cells. This occurs at various levels including the establishment of an immunocompetent T-cell repertoire devoid of autoimmune reactivity, the activation of naive T-cells into active effectors cells and the recognition and destruction of tumor or virus-infected cells. Altogether, understanding the mechanisms involved in the production of antigenic peptides by the proteasome is of crucial importance in order to adapt the mode of delivery of immunotherapeutic vaccines and to define which peptides are the most likely to improve the clinical responses to viruses and cancer.

\section{Acknowledgments}

We are grateful to Julie Klein for her valuable help in the preparation of this manuscript. Nathalie Vigneron is supported by a grant from the Belgium Programme on Interuniversity Poles of Attraction initiated by the Belgian State, prime Minister's Office, Science Policy Programming.

\section{Conflicts of Interest}

The authors declare no conflict of interest.

\section{References}

1. Rock, K.L.; Goldberg, A.L. Degradation of cell proteins and the generation of MHC class I-presented peptides. Annu. Rev. Immunol. 1999, 17, 739-779.

2. Tomko, R.J., Jr.; Hochstrasser, M. Molecular architecture and assembly of the eukaryotic proteasome. Annu. Rev. Biochem. 2013, 82, 415-445.

3. Kisselev, A.F.; Akopian, T.N.; Woo, K.M.; Goldberg, A.L. The sizes of peptides generated from protein by mammalian 26 and 20S proteasomes. J. Biol. Chem. 1999, 274, 3363-3371.

4. Reits, E.; Griekspoor, A.; Neijssen, J.; Groothuis, T.; Jalink, K.; van Veelen, P.; Janssen, H.; Calafat, J.; Drijfhout, J.W.; Neefjes, J. Peptide diffusion, protection, and degradation in nuclear and cytoplasmic compartments before antigen presentation by MHC class I. Immunity 2003, 18, 97-108.

5. Androlewicz, M.J.; Anderson, K.S.; Cresswell, P. Evidence that transporters associated with antigen processing translocate a major histocompatibility complex class I-binding peptide into the endoplasmic reticulum in an ATP-dependent manner. Proc. Natl. Acad. Sci. USA 1993, 90, 9130-9134. 
6. Kageyama, S.; Tsomides, T.J.; Sykulev, Y.; Eisen, H.N. Variations in the number of peptide-MHC class I complexes required to activate cytotoxic T-cell responses. J. Immunol. 1995, 154, 567-576.

7. Coulie, P.G.; Van den Eynde, B.J.; van der Bruggen, P.; Boon, T. Tumour antigens recognized by T-lymphocytes: At the core of cancer immunotherapy. Nat. Rev. Cancer 2014, 14, 135-146.

8. Vigneron, N.; Van den Eynde, B.J. Insights into the processing of MHC class I ligands gained from the study of human tumor epitopes. Cell. Mol. Life Sci. 2011, 68, 1503-1520.

9. Wölfel, T.; Hauer, M.; Schneider, J.; Serrano, M.; Wölfel, C.; Klehmann-Hieb, E.; de Plaen, E.; Hankeln, T.; Meyer zum Büschenfelde, K.-H.; Beach, D. A p16 ${ }^{\mathrm{INK} 4 \mathrm{a}}$-insensitive CDK4 mutant targeted by cytolytic T-lymphocytes in a human melanoma. Science 1995, 269, 1281-1284.

10. Vigneron, N.; Ooms, A.; Morel, S.; Degiovanni, G.; Van den Eynde, B. Identification of a new peptide recognized by autologous cytolytic T-lymphocytes on a human melanoma. Cancer Immun. 2002, 2, 9-18.

11. Coulie, P.G.; Brichard, V.; van Pel, A.; Wölfel, T.; Schneider, J.; Traversari, C.; Mattei, S.; de Plaen, E.; Lurquin, C.; Szikora, J.-P.; et al. A new gene coding for a differentiation antigen recognized by autologous cytolytic T-lymphocytes on HLA-A2 melanomas. J. Exp. Med. 1994, 180, 35-42.

12. Kawakami, Y.; Eliyahu, S.; Jennings, C.; Sakaguchi, K.; Kang, X.; Southwood, S.; Robbins, P.F.; Sette, A.; Appella, E.; Rosenberg, S.A. Recognition of multiple epitopes in the human melanoma antigen gp100 by tumor-infiltrating T-lymphocytes associated with in vivo tumor regression. J. Immunol. 1995, 154, 3961-3968.

13. Van der Bruggen, P.; Traversari, C.; Chomez, P.; Lurquin, C.; de Plaen, E.; Van den Eynde, B.; Knuth, A.; Boon, T. A gene encoding an antigen recognized by cytolytic T-lymphocytes on a human melanoma. Science 1991, 254, 1643-1647.

14. Michalek, M.T.; Grant, E.P.; Gramm, C.; Goldberg, A.L.; Rock, K.L. A role for the ubiquitin-dependent proteolytic pathway in MHC class I-restricted antigen presentation. Nature 1993, 363, 552-554.

15. Ben-Shahar, S.; Cassouto, B.; Novak, L.; Porgador, A.; Reiss, Y. Production of a specific major histocompatibility complex class I-restricted epitope by ubiquitin-dependent degradation of modified ovalbumin in lymphocyte lysate. J. Biol. Chem. 1997, 272, 21060-21066.

16. Grant, E.P.; Michalek, M.T.; Goldberg, A.L.; Rock, K.L. Rate of antigen degradation by the ubiquitin-proteasome pathway influences MHC class I presentation. J. Immunol. 1995, 155, 3750-3758.

17. Townsend, A.; Bastin, J.; Gould, K.; Brownlee, G.; Andrew, M.; Coupar, B.; Boyle, D.; Chan, S.; Smith, G. Defective presentation to class I-restricted cytotoxic T-lymphocytes in vaccinia-infected cells is overcome by enhanced degradation of antigen. J. Exp. Med. 1988, 168, 1211-1224.

18. Kwon, Y.T.; Reiss, Y.; Fried, V.A.; Hershko, A.; Yoon, J.K.; Gonda, D.K.; Sangan, P.; Copeland, N.G.; Jenkins, N.A.; Varshavsky, A. The mouse and human genes encoding the recognition component of the N-end rule pathway. Proc. Natl. Acad. Sci. USA 1998, 95, 7898-7903.

19. Rock, K.L.; Gramm, C.; Rothstein, L.; Clark, K.; Stein, R.; Dick, L.; Hwang, D.; Goldberg, A.L. Inhibitors of the proteasome block the degradation of most cell proteins and the generation of peptides presented on MHC class I molecules. Cell 1994, 78, 761-771. 
20. Morel, S.; Lévy, F.; Burlet-Schiltz, O.; Brasseur, F.; Probst-Kepper, M.; Peitrequin, A.-L.; Monsarrat, B.; van Velthoven, R.; Cerottini, J.-C.; Boon, T.; et al. Processing of some antigens by the standard proteasome but not by the immunoproteasome results in poor presentation by dendritic cells. Immunity 2000, 12, 107-117.

21. Ottaviani, S.; Zhang, Y.; Boon, T.; van der Bruggen, P. A MAGE-1 antigenic peptide recognized by human cytolytic T-lymphocytes on HLA-A2 tumor cells. Cancer Immunol. Immunother. 2005, $54,1214-1220$.

22. Vigneron, N.; Stroobant, V.; Chapiro, J.; Ooms, A.; Degiovanni, G.; Morel, S.; van der Bruggen, P.; Boon, T.; Van den Eynde, B. An antigenic peptide produced by peptide splicing in the proteasome. Science 2004, 304, 587-590.

23. Cerundolo, V.; Benham, A.; Braud, V.; Mukherjee, S.; Gould, K.; Macino, B.; Neefjes, J.; Townsend, A. The proteasome-specific inhibitor lactacystin blocks presentation of cytotoxic T-lymphocyte epitopes in human and murine cells. Eur. J. Immunol. 1997, 27, 336-341.

24. Harding, C.V.; France, J.; Song, R.; Farah, J.M.; Chatterjee, S.; Iqbal, M.; Siman, R. Novel dipeptide aldehydes are proteasome inhibitors and block the MHC-I antigen-processing pathway. J. Immunol. 1995, 155, 1767-1775.

25. Yang, B.; Hahn, Y.S.; Hahn, C.S.; Braciale, T.J. The requirement for proteasome activity class I major histocompatibility complex antigen presentation is dictated by the length of preprocessed antigen. J. Exp. Med. 1996, 183, 1545-1552.

26. Niedermann, G.; Butz, S.; Ihlenfeldt, H.G.; Grimm, R.; Lucchiari, M.; Hoschutzky, H.; Jung, G.; Maier, B.; Eichmann, K. Contribution of proteasome-mediated proteolysis to the hierarchy of epitopes presented by major histocompatibility complex class I molecules. Immunity 1995, 2, 289-299.

27. Vinitsky, A.; Anton, L.C.; Snyder, H.L.; Orlowski, M.; Bennink, J.R.; Yewdell, J.W. The generation of MHC class I-associated peptides is only partially inhibited by proteasome inhibitors-involvement of nonproteasomal cytosolic proteases in antigen processing? J. Immunol. 1997, 159, 554-564.

28. Craiu, A.; Akopian, T.; Goldberg, A.; Rock, K.L. Two distinct proteolytic processes in the generation of a major histocompatibility complex class I-presented peptide. Proc. Natl. Acad. Sci. USA 1997, 94, 10850-10855.

29. Milner, E.; Gutter-Kapon, L.; Bassani-Strenberg, M.; Barnea, E.; Beer, I.; Admon, A. The effect of proteasome inhibition on the generation of the human leukocyte antigen (HLA) peptidome. Mol. Cell. Proteomics 2013, 12, 1853-1864.

30. Nawrocki, S.T.; Carew, J.S.; Dunner, K., Jr.; Boise, L.H.; Chiao, P.J.; Huang, P.; Abbruzzese, J.L.; McConkey, D.J. Bortezomib inhibits PKR-like endoplasmic reticulum (ER) kinase and induces apoptosis via ER stress in human pancreatic cancer cells. Cancer. Res. 2005, 65, 11510-11519.

31. Chapiro, J.; Claverol, S.; Piette, F.; Ma, W.; Stroobant, V.; Guillaume, B.; Gairin, J.-E.; Morel, S.; Burlet-Schiltz, O.; Monsarrat, B.; et al. Destructive cleavage of antigenic peptides either by the immunoproteasome or by the standard proteasome results in differential antigen presentation. J. Immunol. 2006, 176, 1053-1061. 
32. Guillaume, B.; Chapiro, J.; Stroobant, V.; Colau, D.; van Holle, B.; Parvizi, G.; Bousquet-Dubouch, M.P.; Theate, I.; Parmentier, N.; Van den Eynde, B.J. Two abundant proteasome subtypes that uniquely process some antigens presented by HLA class I molecules. Proc. Natl. Acad. Sci. USA 2010, 107, 18599-18604.

33. Gelman, J.S.; Sironi, J.; Berezniuk, I.; Dasgupta, S.; Castro, L.M.; Gozzo, F.C.; Ferro, E.S.; Fricker, L.D. Alterations of the intracellular peptidome in response to the proteasome inhibitor bortezomib. PLoS One 2013, 8, e53263.

34. Mo, X.Y.; Cascio, P.; Lemerise, K.; Goldberg, A.L.; Rock, K. Distinct proteolytic processes generate the $\mathrm{C}$ and $\mathrm{N}$ termini of MHC class I-binding peptides. J. Immunol. 1999, 163, 5851-5859.

35. Reits, E.; Neijssen, J.; Herberts, C.; Benckhuijsen, W.; Janssen, L.; Drijfhout, J.W.; Neefjes, J. A major role for TPPII in trimming proteasomal degradation products for MHC class I antigen presentation. Immunity 2004, 20, 495-506.

36. Saric, T.; Chang, S.C.; Hattori, A.; York, I.A.; Markant, S.; Rock, K.L.; Tsujimoto, M.; Goldberg, A.L. An IFN- $\gamma$-induced aminopeptidase in the ER, ERAP1, trims precursors to MHC class I-presented peptides. Nat. Immunol. 2002, 3, 1169-1176.

37. Kanaseki, T.; Blanchard, N.; Hammer, G.E.; Gonzalez, F.; Shastri, N. ERAAP synergizes with MHC class I molecules to make the final cut in the antigenic peptide precursors in the endoplasmic reticulum. Immunity 2006, 25, 795-806.

38. Guillaume, B.; Stroobant, V.; Bousquet-Dubouch, M.P.; Colau, D.; Chapiro, J.; Parmentier, N.; Dalet, A.; Van den Eynde, B.J. Analysis of the processing of seven human tumor antigens by intermediate proteasomes. J. Immunol. 2012, 189, 3538-3547.

39. Luckey, C.J.; King, G.M.; Marto, J.A.; Venketeswaran, S.; Maier, B.F.; Crotzer, V.L.; Colella, T.A.; Shabanowitz, J.; Hunt, D.F.; Engelhard, V.H. Proteasomes can either generate or destroy MHC class I epitopes: Evidence for nonproteasomal epitope generation in the cytosol. J. Immunol. 1998, $161,112-121$.

40. Seifert, U.; Maranon, C.; Shmueli, A.; Desoutter, J.F.; Wesoloski, L.; Janek, K.; Henklein, P.; Diescher, S.; Andrieu, M.; de la Salle, H.; et al. An essential role for tripeptidyl peptidase in the generation of an MHC class I epitope. Nat. Immunol. 2003, 4, 375-379.

41. Guil, S.; Rodriguez-Castro, M.; Aguilar, F.; Villasevil, E.M.; Anton, L.C.; del Val, M. Need for tripeptidyl-peptidase II in major histocompatibility complex class I viral antigen processing when proteasomes are detrimental. J. Biol. Chem. 2006, 281, 39925-39934.

42. Diekmann, J.; Adamopoulou, E.; Beck, O.; Rauser, G.; Lurati, S.; Tenzer, S.; Einsele, H.; Rammensee, H.G.; Schild, H.; Topp, M.S. Processing of two latent membrane protein 1 MHC class I epitopes requires tripeptidyl peptidase II involvement. J. Immunol. 2009, 183, 1587-1597.

43. Parmentier, N.; Stroobant, V.; Colau, D.; de Diesbach, P.; Morel, S.; Chapiro, J.; Van Endert, P.; Van den Eynde, B.J. Production of an antigenic peptide by insulin-degrading enzyme. Nat. Immunol. 2010, 11, 449-454.

44. Kessler, J.H.; Khan, S.; Seifert, U.; le Gall, S.; Chow, K.M.; Paschen, A.; Bres-Vloemans, S.A.; de Ru, A.; van Montfoort, N.; Franken, K.L.; et al. Antigen processing by nardilysin and thimet oligopeptidase generates cytotoxic T-cell epitopes. Nat. Immunol. 2011, 12, 45-53. 
45. Kessler, B.; Hong, X.; Petrovic, J.; Borodovsky, A.; Dantuma, N.P.; Bogyo, M.; Overkleeft, H.S.; Ploegh, H.; Glas, R. Pathways accessory to proteasomal proteolysis are less efficient in major histocompatibility complex class I antigen production. J. Biol. Chem. 2003, 278, 10013-10021.

46. Van Endert, P. Role of tripeptidyl peptidase II in MHC class I antigen processing-The end of controversies? Eur. J. Immunol. 2008, 38, 609-613.

47. Culina, S.; Mauvais, F.X.; Hsu, H.T.; Burgevin, A.; Guenette, S.; Moser, A.; van Endert, P. No major role for insulin-degrading enzyme in antigen presentation by MHC molecules. PLoS One 2014, 9, e88365.

48. El Hage, F.; Stroobant, V.; Vergnon, I.; Baurain, J.F.; Echchakir, H.; Lazar, V.; Chouaib, S.; Coulie, P.G.; Mami-Chouaib, F. Preprocalcitonin signal peptide generates a cytotoxic T-lymphocyte-defined tumor epitope processed by a proteasome-independent pathway. Proc. Natl. Acad. Sci. USA 2008, 105, 10119-10124.

49. Wölfel, C.; Drexler, I.; van Pel, A.; Thres, T.; Leister, N.; Herr, W.; Sutter, G.; Huber, C.; Wölfel, T. Transporter (TAP)- and proteasome-independent presentation of a melanoma-associated tyrosinase epitope. Int. J. Cancer 2000, 88, 432-438.

50. Leonhardt, R.M.; Fiegl, D.; Rufer, E.; Karger, A.; Bettin, B.; Knittler, M.R. Post-endoplasmic reticulum rescue of unstable MHC class I requires proprotein convertase PC7. J. Immunol. 2010, 184, 2985-2998.

51. Gil-Torregrosa, B.C.; Raul Castano, A.; del Val, M. Major histocompatibility complex class I viral antigen processing in the secretory pathway defined by the trans-Golgi network protease furin. J. Exp. Med. 1998, 188, 1105-1116.

52. Tey, S.K.; Khanna, R. Autophagy mediates transporter associated with antigen processing-independent presentation of viral epitopes through MHC class I pathway. Blood 2012, 120, 994-1004.

53. English, L.; Chemali, M.; Duron, J.; Rondeau, C.; Laplante, A.; Gingras, D.; Alexander, D.; Leib, D.; Norbury, C.; Lippe, R.; et al. Autophagy enhances the presentation of endogenous viral antigens on MHC class I molecules during HSV-1 infection. Nat. Immunol. 2009, 10, 480-487.

54. Demachi-Okamura, A.; Torikai, H.; Akatsuka, Y.; Miyoshi, H.; Yoshimori, T.; Kuzushima, K. Autophagy creates a CTL epitope that mimics tumor-associated antigens. PLoS One 2012, 7, e47126.

55. Hanada, K.; Yewdell, J.W.; Yang, J.C. Immune recognition of a human renal cancer antigen through post-translational protein splicing. Nature 2004, 427, 252-256.

56. Dalet, A.; Stroobant, V.; Vigneron, N.; Van den Eynde, B.J. Differences in the production of spliced antigenic peptides by the standard proteasome and the immunoproteasome. Eur. J. Immunol. 2011, 41, 39-46.

57. Michaux, A.; Larrieu, P.; Stroobant, V.; Fonteneau, J.F.; Jotereau, F.; Van den Eynde, B.J.; Moreau-Aubry, A.; Vigneron, N. A spliced antigenic peptide comprising a single spliced amino acid is produced in the proteasome by reverse splicing of a longer peptide fragment followed by trimming. J. Immunol. 2014, 192, 1962-1971.

58. Wölfel, T.; van Pel, A.; Brichard, V.; Schneider, J.; Seliger, B.; Meyer zum Büschenfelde, K.-H.; Boon, T. Two tyrosinase nonapeptides recognized on HLA-A2 melanomas by autologous cytolytic T-lymphocytes. Eur. J. Immunol. 1994, 24, 759-764. 
59. Dalet, A.; Robbins, P.F.; Stroobant, V.; Vigneron, N.; Li, Y.F.; El-Gamil, M.; Hanada, K.; Yang, J.C.; Rosenberg, S.A.; Van den Eynde, B.J. An antigenic peptide produced by reverse splicing and double asparagine deamidation. Proc. Natl. Acad. Sci. USA 2011, 108, E323-E331.

60. Kawakami, Y.; Eliyahu, S.; Sakaguchi, K.; Robbins, P.F.; Rivoltini, L.; Yannelli, J.R.; Appella, E.; Rosenberg, S.A. Identification of the immunodominant peptides of the MART-1 human melanoma antigen recognized by the majority of HLA-A2-restricted tumor infiltrating lymphocytes. J. Exp. Med. 1994, 180, 347-352.

61. Schultz, E.S.; Chapiro, J.; Lurquin, C.; Claverol, S.; Burlet-Schiltz, O.; Warnier, G.; Russo, V.; Morel, S.; Levy, F.; Boon, T.; et al. The production of a new MAGE-3 peptide presented to cytolytic T-lymphocytes by HLA-B40 requires the immunoproteasome. J. Exp. Med. 2002, 195, 391-399.

62. Van der Bruggen, P.; Bastin, J.; Gajewski, T.; Coulie, P.G.; Boël, P.; de Smet, C.; Traversari, C.; Townsend, A.; Boon, T. A peptide encoded by human gene MAGE-3 and presented by HLA-A2 induces cytolytic T-lymphocytes that recognize tumor cells expressing MAGE-3. Eur. J. Immunol. 1994, 24, 3038-3043.

63. Huang, L.-Q.; Brasseur, F.; Serrano, A.; de Plaen, E.; van der Bruggen, P.; Boon, T.; van Pel, A. Cytolytic T-lymphocytes recognize an antigen encoded by MAGE-A10 on a human melanoma. J. Immunol. 1999, 162, 6849-6854.

64. Ma, W.; Germeau, C.; Vigneron, N.; Maernoudt, A.-S.; Morel, S.; Boon, T.; Coulie, P.G.; Van den Eynde, B. Two new tumor-specific antigenic peptides encoded by gene $M A G E-C 2$ and presented to cytolytic T-lymphocytes by HLA-A2. Int. J. Cancer 2004, 109, 698-702.

65. Ma, W.; Vigneron, N.; Chapiro, J.; Stroobant, V.; Germeau, C.; Boon, T.; Coulie, P.G.; van den Eynde, B.J. A MAGE-C2 antigenic peptide processed by the immunoproteasome is recognized by cytolytic T-cells isolated from a melanoma patient after successful immunotherapy. Int. J. Cancer 2011, 129, 2427-2434.

66. Corbière, V.; Chapiro, J.; Stroobant, V.; Ma, W.; Lurquin, C.; Lethe, B.; Van Baren, N.; van den Eynde, B.J.; Boon, T.; Coulie, P.G. Antigen spreading contributes to MAGE vaccination-induced regression of melanoma metastases. Cancer. Res. 2011, 71, 1253-1262.

67. Robbins, P.F.; Lu, Y.C.; El-Gamil, M.; Li, Y.F.; Gross, C.; Gartner, J.; Lin, J.C.; Teer, J.K.; Cliften, P.; Tycksen, E.; et al. Mining exomic sequencing data to identify mutated antigens recognized by adoptively transferred tumor-reactive T-cells. Nat. Med. 2013, 19, 747-752.

68. Warren, E.H.; Vigneron, N.J.; Gavin, M.A.; Coulie, P.G.; Stroobant, V.; Dalet, A.; Tykodi, S.S.; Xuereb, S.M.; Mito, J.K.; Riddell, S.R.; et al. An antigen produced by splicing of noncontiguous peptides in the reverse order. Science 2006, 313, 1444-1447.

69. Löwe, J.; Stock, D.; Jap, B.; Zwickl, P.; Baumeister, W.; Huber, R. Crystal structure of the 20S proteasome from the archaeon T. acidophilum at $3.4 \AA$ resolution. Science 1995, 268, 533-539.

70. Groll, M.; Ditzel, L.; Löwe, J.; Stock, D.; Bochtler, M.; Bartunik, H.D.; Huber, R. Structure of 20S proteasome from yeast at $2.4 \AA$ resolution. Nature 1997, 386, 463-471.

71. Seemuller, E.; Lupas, A.; Stock, D.; Lowe, J.; Huber, R.; Baumeister, W. Proteasome from Thermoplasma acidophilum: A threonine protease. Science 1995, 268, 579-582. 
72. Heinemeyer, W.; Fischer, M.; Krimmer, T.; Stachon, U.; Wolf, D.H. The active sites of the eukaryotic $20 \mathrm{~S}$ proteasome and their involvement in subunit precursor processing. J. Biol. Chem. 1997, 272, 25200-25209.

73. Groll, M.; Huber, R. Substrate access and processing by the 20 S proteasome core particle. Int. J. Biochem. Cell Biol. 2003, 35, 606-616.

74. Dalet, A.; Vigneron, N.; Stroobant, V.; Hanada, K.; Van den Eynde, B.J. Splicing of distant peptide fragments occurs in the proteasome by transpeptidation and produces the spliced antigenic peptide derived from fibroblast growth factor-5. J. Immunol. 2010, 184, 3016-3024.

75. Mishto, M.; Goede, A.; Taube, K.T.; Keller, C.; Janek, K.; Henklein, P.; Niewienda, A.; Kloss, A.; Gohlke, S.; Dahlmann, B.; et al. Driving forces of proteasome-catalyzed peptide splicing in yeast and humans. Mol. Cell. Proteomics 2012, 11, 1008-1023.

76. Liepe, J.; Mishto, M.; Textoris-Taube, K.; Janek, K.; Keller, C.; Henklein, P.; Kloetzel, P.M.; Zaikin, A. The 20S proteasome splicing activity discovered by SpliceMet. PLoS Comput. Biol. 2010, 6, e1000830.

77. Van der Bruggen, P.; Zhang, Y.; Chaux, P.; Stroobant, V.; Panichelli, C.; Schultz, E.S.; Chapiro, J.; Van den Eynde, B.J.; Brasseur, F.; Boon, T. Tumor-specific shared antigenic peptides recognized by human T-cells. Immunol. Rev. 2002, 188, 51-64.

78. Baumeister, W.; Walz, J.; Zühl, F.; Seemüller, E. The proteasome: Paradigm of a self-compartmentalizing protease. Cell 1998, 92, 367-380.

79. Unno, M.; Mizushima, T.; Morimoto, Y.; Tomisugi, Y.; Tanaka, K.; Yasuoka, N.; Tsukihara, T. The structure of the mammalian $20 \mathrm{~S}$ proteasome at $2.75 \AA$ resolution. Structure 2002, 10, 609-618.

80. Davies, K.J. Degradation of oxidized proteins by the 20S proteasome. Biochimie 2001, 83, 301-310.

81. Pickering, A.M.; Koop, A.L.; Teoh, C.Y.; Ermak, G.; Grune, T.; Davies, K.J. The immunoproteasome, the $20 \mathrm{~S}$ proteasome and the PA28 $\alpha \beta$ proteasome regulator are oxidative-stress-adaptive proteolytic complexes. Biochem. J. 2010, 432, 585-594.

82. Brooks, P.; Fuertes, G.; Murray, R.Z.; Bose, S.; Knecht, E.; Rechsteiner, M.C.; Hendil, K.B.; Tanaka, K.; Dyson, J.; Rivett, J. Subcellular localization of proteasomes and their regulatory complexes in mammalian cells. Biochem. J. 2000, 346, 155-161.

83. Peters, J.M.; Franke, W.W.; Kleinschmidt, J.A. Distinct $19 \mathrm{~S}$ and $20 \mathrm{~S}$ subcomplexes of the $26 \mathrm{~S}$ proteasome and their distribution in the nucleus and the cytoplasm. J. Biol. Chem. 1994, 269, 7709-7718.

84. Baugh, J.M.; Viktorova, E.G.; Pilipenko, E.V. Proteasomes can degrade a significant proportion of cellular proteins independent of ubiquitination. J. Mol. Biol. 2009, 386, 814-827.

85. Whittier, J.E.; Xiong, Y.; Rechsteiner, M.C.; Squier, T.C. Hsp90 enhances degradation of oxidized calmodulin by the 20S proteasome. J. Biol. Chem. 2004, 279, 46135-46142.

86. Orlowski, M. Selective activation of the $20 \mathrm{~S}$ proteasome (multicatalytic proteinase complex) by histone H3. Biochemistry 2001, 40, 15318-15326.

87. Kisselev, A.F.; Kaganovich, D.; Goldberg, A.L. Binding of hydrophobic peptides to several non-catalytic sites promotes peptide hydrolysis by all active sites of $20 \mathrm{~S}$ proteasomes. Evidence for peptide-induced channel opening in the $\alpha$-rings. J. Biol. Chem. 2002, 277, 22260-22270.

88. Wang, X.; Yen, J.; Kaiser, P.; Huang, L. Regulation of the $26 \mathrm{~S}$ proteasome complex during oxidative stress. Sci. Signal. 2010, doi:10.1126/scisignal.2001232. 
89. Grune, T.; Catalgol, B.; Licht, A.; Ermak, G.; Pickering, A.M.; Ngo, J.K.; Davies, K.J. Hsp70 mediates dissociation and reassociation of the $26 \mathrm{~S}$ proteasome during adaptation to oxidative stress. Free Radic. Biol. Med. 2011, 51, 1355-1364.

90. Bajorek, M.; Finley, D.; Glickman, M.H. Proteasome disassembly and downregulation is correlated with viability during stationary phase. Curr. Biol. 2003, 13, 1140-1144.

91. Aiken, C.T.; Kaake, R.M.; Wang, X.; Huang, L. Oxidative stress-mediated regulation of proteasome complexes. Mol. Cell. Proteomics 2011, doi:10.1074/mcp.M110.006924.

92. Li, J.; Powell, S.R.; Wang, X. Enhancement of proteasome function by PA28 $\alpha$; overexpression protects against oxidative stress. FASEB J. 2011, 25, 883-893.

93. Griffin, T.A.; Nandi, D.; Cruz, M.; Fehling, H.J.; van Kaer, L.; Monaco, J.J.; Colbert, R.A. Immunoproteasome assembly: Cooperative incorporation of interferon $\gamma(\mathrm{IFN}-\gamma)$-inducible subunits. J. Exp. Med. 1998, 187, 97-104.

94. Enenkel, C.; Lehmann, H.; Kipper, J.; Guckel, R.; Hilt, W.; Wolf, D.H. PRE3, highly homologous to the human major histocompatibility complex-linked LMP2 (RING12) gene, codes for a yeast proteasome subunit necessary for the peptidylglutamyl-peptide hydrolyzing activity. FEBS Lett. 1994, 341, 193-196.

95. Dick, T.P.; Nussbaum, A.K.; Deeg, M.; Heinemeyer, W.; Groll, M.; Schirle, M.; Keilholz, W.; Stevanovic, S.; Wolf, D.H.; Huber, R.; et al. Contribution of proteasomal $\beta$-subunits to the cleavage of peptide substrates analyzed with yeast mutants. J. Biol. Chem. 1998, 273, 25637-25646.

96. Nussbaum, A.K.; Dick, T.P.; Keilholz, W.; Schirle, M.; Stevanovic, S.; Dietz, K.; Heinemeyer, W.; Groll, M.; Wolf, D.H.; Huber, R.; et al. Cleavage motifs of the yeast $20 \mathrm{~S}$ proteasome $\beta$ subunits deduced from digests of enolase 1. Proc. Natl. Acad. Sci. USA 1998, 95, 12504-12509.

97. Toes, R.E.M.; Nussbaum, A.K.; Degermann, S.; Schirle, M.; Emmerich, N.P.N.; Kraft, M.; Laplace, C.; Zwinderman, A.; Dick, T.P.; Müller, J.; et al. Discrete cleavage motifs of constitutive and immunoproteasomes revealed by quantitative analysis of cleavage products. J. Exp. Med. 2001, 194, 1-12.

98. Gaczynska, M.; Rock, K.L.; Goldberg, A.L. $\gamma$-interferon and expression of MHC genes regulate peptide hydrolysis by proteasomes. Nature 1993, 365, 264-267.

99. Gaczynska, M.; Rock, K.L.; Spies, T.; Goldberg, A.L. Peptidase activities of proteasomes are differentially regulated by the major histocompatibility complex-encoded genes for LMP2 and LMP7. Proc. Natl. Acad. Sci. USA 1994, 91, 9213-9217.

100. Driscoll, J.; Brown, M.; Finley, D.; Monaco, J. MHC-linked LMP gene products specifically alter peptidase activities of the proteasome. Nature 1993, 365, 262-264.

101. Boes, B.; Hengel, H.; Ruppert, T.; Multhaup, G.; Koszinowski, U.H.; Kloetzel, P.M. Interferon $\gamma$ stimulation modulates the proteolytic activity and cleavage site preference of $20 \mathrm{~S}$ mouse proteasomes. J. Exp. Med. 1994, 179, 901-909.

102. Fehling, H.J.; Swat, W.; Laplace, C.; Kühn, R.; Rajewsky, K.; Müller, U.; von Boehmer, H. MHC class I expression in mice lacking the proteasome subunit LMP-7. Science 1994, 265, 1234-1237.

103. Van Kaer, L.; Ashton-Rickardt, P.G.; Eichelberger, M.; Gaczynska, M.; Nagashima, K.; Rock, K.L.; Goldberg, A.L.; Doherty, P.C.; Tonegawa, S. Altered peptidase and viral-specific T-cell response in LMP2 mutant mice. Immunity 1994, 1, 533-541. 
104. Kincaid, E.Z.; Che, J.W.; York, I.; Escobar, H.; Reyes-Vargas, E.; Delgado, J.C.; Welsh, R.M.; Karow, M.L.; Murphy, A.J.; Valenzuela, D.M.; et al. Mice completely lacking immunoproteasomes show major changes in antigen presentation. Nat. Immunol. 2012, 13, 129-135.

105. De Verteuil, D.; Muratore-Schroeder, T.L.; Granados, D.P.; Fortier, M.H.; Hardy, M.P.; Bramoulle, A.; Caron, E.; Vincent, K.; Mader, S.; Lemieux, S.; et al. Deletion of immunoproteasome subunits imprints on the transcriptome and has a broad impact on peptides presented by major histocompatibility complex I molecules. Mol. Cell. Proteomics 2010, 9, 2034-2047.

106. Vigneron, N.; Van den Eynde, B.J. Proteasome subtypes and the processing of tumor antigens: Increasing antigenic diversity. Curr. Opin. Immunol. 2012, 24, 84-91.

107. Basler, M.; Lauer, C.; Moebius, J.; Weber, R.; Przybylski, M.; Kisselev, A.F.; Tsu, C.; Groettrup, M. Why the structure but not the activity of the immunoproteasome subunit low molecular mass polypeptide 2 rescues antigen presentation. J. Immunol. 2012, 189, 1868-1877.

108. Chen, W.; Norbury, C.C.; Cho, Y.; Yewdell, J.W.; Bennink, J.R. Immunoproteasomes shape immunodominance hierarchies of antiviral $\mathrm{CD}^{+} \mathrm{T}$-cells at the levels of T-cell repertoire and presentation of viral antigens. J. Exp. Med. 2001, 193, 1319-1326.

109. Chapatte, L.; Ayyoub, M.; Morel, S.; Peitrequin, A.L.; Levy, N.; Servis, C.; Van den Eynde, B.J.; Valmori, D.; Levy, F. Processing of tumor-associated antigen by the proteasomes of dendritic cells controls in vivo T-cell responses. Cancer Res. 2006, 66, 5461-5468.

110. Dannull, J.; Haley, N.R.; Archer, G.; Nair, S.; Boczkowski, D.; Harper, M.; de Rosa, N.; Pickett, N.; Mosca, P.J.; Burchette, J.; et al. Melanoma immunotherapy using mature DCs expressing the constitutive proteasome. J. Clin. Invest. 2013, 123, 3135-3145.

111. Dannull, J.; Lesher, D.T.; Holzknecht, R.; Qi, W.; Hanna, G.; Seigler, H.; Tyler, D.S.; Pruitt, S.K. Immunoproteasome down-modulation enhances the ability of dendritic cells to stimulate antitumor immunity. Blood 2007, 110, 4341-4350.

112. Basler, M.; Moebius, J.; Elenich, L.; Groettrup, M.; Monaco, J.J. An altered T-cell repertoire in MECL-1-deficient mice. J. Immunol. 2006, 176, 6665-6672.

113. Basler, M.; Youhnovski, N.; van den Broek, M.; Przybylski, M.; Groettrup, M. Immunoproteasomes down-regulate presentation of a subdominant T-cell epitope from lymphocytic choriomeningitis virus. J. Immunol. 2004, 173, 3925-3934.

114. Pang, K.C.; Sanders, M.T.; Monaco, J.J.; Doherty, P.C.; Turner, S.J.; Chen, W. Immunoproteasome subunit deficiencies impact differentially on two immunodominant influenza virus-specific $\mathrm{CD}^{+}$ T-cell responses. J. Immunol. 2006, 177, 7680-7688.

115. Hutchinson, S.; Sims, S.; O’Hara, G.; Silk, J.; Gileadi, U.; Cerundolo, V.; Klenerman, P. A dominant role for the immunoproteasome in $\mathrm{CD}^{+} \mathrm{T}$-cell responses to murine cytomegalovirus. PLoS One 2011, 6, e14646.

116. Zimmermann, A.; Trilling, M.; Wagner, M.; Wilborn, M.; Bubic, I.; Jonjic, S.; Koszinowski, U.; Hengel, H. A cytomegaloviral protein reveals a dual role for STAT2 in IFN- $\gamma$ signaling and antiviral responses. J. Exp. Med. 2005, 201, 1543-1553.

117. Dahlmann, B.; Ruppert, T.; Kuehn, L.; Merforth, S.; Kloetzel, P.-M. Different proteasome subtypes in a single tissue exhibit different enzymatic properties. J. Mol. Biol. 2000, 303, 643-653. 
118. Groettrup, M.; Standera, S.; Stohwasser, R.; Kloetzel, P.M. The subunits MECL-1 and LMP2 are mutually required for incorporation into the 20 S proteasome. Proc. Natl. Acad. Sci. USA 1997, 94 , 8970-8975.

119. De, M.; Jayarapu, K.; Elenich, L.; Monaco, J.J.; Colbert, R.A.; Griffin, T.A. $\beta 2$ subunit propeptides influence cooperative proteasome assembly. J. Biol. Chem. 2003, 278, 6153-6159.

120. Kingsbury, D.J.; Griffin, T.A.; Colbert, R.A. Novel propeptide function in 20S proteasome assembly influences $\beta$ subunit composition. J. Biol. Chem. 2000, 275, 24156-24162.

121. Groll, M.; Heinemeyer, W.; Jäger, S.; Ullrich, T.; Bochtler, M.; Wolf, D.H.; Huber, R. The catalytic sites of $20 \mathrm{~S}$ proteasomes and their role in subunit maturation: A mutational and crystallographic study. Proc. Natl. Acad. Sci. USA 1999, 96, 10976-10983.

122. Klare, N.; Seeger, M.; Janek, K.; Jungblut, P.R.; Dahlmann, B. Intermediate-type 20S proteasomes in HeLa cells: "Asymmetric" subunit composition, diversity and adaptation. J. Mol. Biol. 2007, $373,1-10$.

123. Murata, S.; Sasaki, K.; Kishimoto, T.; Niwa, S.; Hayashi, H.; Takahama, Y.; Tanaka, K. Regulation of $\mathrm{CD}^{+} \mathrm{T}$-cell development by thymus-specific proteasomes. Science 2007, 316, 1349-1353.

124. Tomaru, U.; Ishizu, A.; Murata, S.; Miyatake, Y.; Suzuki, S.; Takahashi, S.; Kazamaki, T.; Ohara, J.; Baba, T.; Iwasaki, S.; et al. Exclusive expression of proteasome subunit $\beta 5 \mathrm{t}$ in the human thymic cortex. Blood 2009, 113, 5186-5191.

125. Nitta, T.; Murata, S.; Sasaki, K.; Fujii, H.; Ripen, A.M.; Ishimaru, N.; Koyasu, S.; Tanaka, K.; Takahama, Y. Thymoproteasome shapes immunocompetent repertoire of $\mathrm{CD} 8^{+} \mathrm{T}$-cells. Immunity 2010, 32, 29-40.

126. Ziegler, A.; Muller, C.A.; Bockmann, R.A.; Uchanska-Ziegler, B. Low-affinity peptides and T-cell selection. Trends Immunol. 2009, 30, 53-60.

127. Xing, Y.; Jameson, S.C.; Hogquist, K.A. Thymoproteasome subunit- $\beta 5 \mathrm{t}$ generates peptide-MHC complexes specialized for positive selection. Proc. Natl. Acad. Sci. USA 2013, 110, 6979-6984.

128. Groettrup, M.; Kirk, C.J.; Basler, M. Proteasomes in immune cells: more than peptide producers? Nat. Rev. Immunol. 2010, 10, 73-78.

129. Gotter, J.; Brors, B.; Hergenhahn, M.; Kyewski, B. Medullary epithelial cells of the human thymus express a highly diverse selection of tissue-specific genes colocalized in chromosomal clusters. J. Exp. Med. 2004, 199, 155-166.

130. Huijbers, I.J.; Soudja, S.M.; Uyttenhove, C.; Buferne, M.; Inderberg-Suso, E.M.; Colau, D.; Pilotte, L.; Chomez, P.; Brasseur, F.; Schmitt-Verhulst, A.M.; et al. Minimal tolerance to a tumor antigen encoded by a cancer-germline gene. J. Immunol. 2012, 188, 111-121.

131. Huber, E.M.; Basler, M.; Schwab, R.; Heinemeyer, W.; Kirk, C.J.; Groettrup, M.; Groll, M. Immuno- and constitutive proteasome crystal structures reveal differences in substrate and inhibitor specificity. Cell 2012, 148, 727-738.

132. Sijts, A.J.A.M.; Ruppert, T.; Rehermann, B.; Schmidt, M.; Koszinowski, U.; Kloetzel, P.-M. Efficient generation of a hepatitis B virus cytotoxic T-lymphocyte epitope requires the structural features of immunoproteasomes. J. Exp. Med. 2000, 191, 503-513.

133. Seifert, U.; Bialy, L.P.; Ebstein, F.; Bech-Otschir, D.; Voigt, A.; Schroter, F.; Prozorovski, T.; Lange, N.; Steffen, J.; Rieger, M.; et al. Immunoproteasomes preserve protein homeostasis upon interferon-induced oxidative stress. Cell 2010, 142, 613-624. 
134. Nathan, J.A.; Spinnenhirn, V.; Schmidtke, G.; Basler, M.; Groettrup, M.; Goldberg, A.L. Immuno- and constitutive proteasomes do not differ in their abilities to degrade ubiquitinated proteins. Cell 2013, 152, 1184-1194.

135. Hayashi, T.; Faustman, D. NOD mice are defective in proteasome production and activation of NF-кB. Mol. Cell. Biol. 1999, 19, 8646-8659.

136. Kessler, B.M.; Lennon-Dumenil, A.M.; Shinohara, M.L.; Lipes, M.A.; Ploegh, H.L. LMP2 expression and proteasome activity in NOD mice. Nat. Med. 2000, 6, 1064.

137. Runnels, H.A.; Watkins, W.A.; Monaco, J.J. LMP2 expression and proteasome activity in NOD mice. Nat. Med. 2000, 6, 1064-1065.

138. Hensley, S.E.; Zanker, D.; Dolan, B.P.; David, A.; Hickman, H.D.; Embry, A.C.; Skon, C.N.; Grebe, K.M.; Griffin, T.A.; Chen, W.; et al. Unexpected role for the immunoproteasome subunit LMP2 in antiviral humoral and innate immune responses. J. Immunol. 2010, 184, 4115-4122.

139. Moebius, J.; van den Broek, M.; Groettrup, M.; Basler, M. Immunoproteasomes are essential for survival and expansion of T-cells in virus-infected mice. Eur. J. Immunol. 2010, 40, 3439-3449.

140. Maldonado, M.; Kapphahn, R.J.; Terluk, M.R.; Heuss, N.D.; Yuan, C.; Gregerson, D.S.; Ferrington, D.A. Immunoproteasome deficiency modifies the alternative pathway of NF- $\kappa \mathrm{B}$ signaling. PLoS One 2013, 8, e56187.

141. Muchamuel, T.; Basler, M.; Aujay, M.A.; Suzuki, E.; Kalim, K.W.; Lauer, C.; Sylvain, C.; Ring, E.R.; Shields, J.; Jiang, J.; et al. A selective inhibitor of the immunoproteasome subunit LMP7 blocks cytokine production and attenuates progression of experimental arthritis. Nat. Med. 2009, 15, 781-787.

142. Pickart, C.M. Mechanisms underlying ubiquitination. Annu. Rev. Biochem. 2001, 70, 503-533.

143. Forster, F.; Unverdorben, P.; Sledz, P.; Baumeister, W. Unveiling the long-held secrets of the 26S proteasome. Structure 2013, 21, 1551-1562.

144. Yao, T.; Cohen, R.E. A cryptic protease couples deubiquitination and degradation by the proteasome. Nature 2002, 419, 403-407.

145. Verma, R.; Aravind, L.; Oania, R.; McDonald, W.H.; Yates, J.R., 3rd; Koonin, E.V.; Deshaies, R.J. Role of Rpn11 metalloprotease in deubiquitination and degradation by the $26 \mathrm{~S}$ proteasome. Science 2002, 298, 611-615.

146. Pathare, G.R.; Nagy, I.; Bohn, S.; Unverdorben, P.; Hubert, A.; Korner, R.; Nickell, S.; Lasker, K.; Sali, A.; Tamura, T.; et al. The proteasomal subunit Rpn6 is a molecular clamp holding the core and regulatory subcomplexes together. Proc. Natl. Acad. Sci. USA 2012, 109, 149-154.

147. Tanahashi, N.; Murakami, Y.; Minami, Y.; Shimbara, N.; Hendil, K.B.; Tanaka, K. Hybrid proteasomes. Induction by interferon- $\gamma$ and contribution to ATP-dependent proteolysis. J. Biol. Chem. 2000, 275, 14336-14345.

148. Ustrell, V.; Hoffman, L.; Pratt, G.; Rechsteiner, M. PA200, a nuclear proteasome activator involved in DNA repair. EMBO J. 2002, 21, 3516-3525.

149. Ma, C.P.; Slaughter, C.A.; DeMartino, G.N. Identification, purification, and characterization of a protein activator (PA28) of the $20 \mathrm{~S}$ proteasome (macropain). J. Biol. Chem. 1992, 267, 10515-10523.

150. Dubiel, W.; Pratt, G.; Ferrell, K.; Rechsteiner, M. Purification of an $11 \mathrm{~S}$ regulator of the multicatalytic protease. J. Biol. Chem. 1992, 267, 22369-22377.

151. Rechsteiner, M.; Realini, C.; Ustrell, V. The proteasome activator 11S REG (PA28) and class I antigen presentation. Biochem. J. 2000, 345, 1-15. 
152. Realini, C.; Dubiel, W.; Pratt, G.; Ferrell, K.; Rechsteiner, M. Molecular cloning and expression of a $\gamma$-interferon-inducible activator of the multicatalytic protease. J. Biol. Chem. 1994, 269, 20727-20732.

153. Ahn, J.Y.; Tanahashi, N.; Akiyama, K.; Hisamatsu, H.; Noda, C.; Tanaka, K.; Chung, C.H.; Shibmara, N.; Willy, P.J.; Mott, J.D.; et al. Primary structures of two homologous subunits of PA28, a $\gamma$-interferon-inducible protein activator of the $20 \mathrm{~S}$ proteasome. FEBS Lett. 1995, 366, $37-42$.

154. Gray, C.W.; Slaughter, C.A.; DeMartino, G.N. PA28 activator protein forms regulatory caps on proteasome stacked rings. J. Mol. Biol. 1994, 236, 7-15.

155. Knowlton, J.R.; Johnston, S.C.; Whitby, F.G.; Realini, C.; Zhang, Z.; Rechsteiner, M.; Hill, C.P. Structure of the proteasome activator REG $\alpha$ (PA28 $\alpha$ ). Nature 1997, 390, 639-643.

156. Zhang, Z.; Krutchinsky, A.; Endicott, S.; Realini, C.; Rechsteiner, M.; Standing, K.G. Proteasome activator 11S REG or PA28: Recombinant REG $\alpha /$ REG $\beta$ hetero-oligomers are heptamers. Biochemistry 1999, 38, 5651-5658.

157. Hendil, K.B.; Khan, S.; Tanaka, K. Simultaneous binding of PA28 and PA700 activators to 20S proteasomes. Biochem. J. 1998, 332, 749-754.

158. Cascio, P.; Call, M.; Petre, B.M.; Walz, T.; Goldberg, A.L. Properties of the hybrid form of the 26S proteasome containing both $19 \mathrm{~S}$ and PA28 complexes. EMBO J. 2002, 21, 2636-2645.

159. DeMartino, G.N.; Slaughter, C.A. The proteasome, a novel protease regulated by multiple mechanisms. J. Biol. Chem. 1999, 274, 22123-22126.

160. Whitby, F.G.; Masters, E.I.; Kramer, L.; Knowlton, J.R.; Yao, Y.; Wang, C.C.; Hill, C.P. Structural basis for the activation of $20 \mathrm{~S}$ proteasomes by $11 \mathrm{~S}$ regulators. Nature 2000, 408, 115-120.

161. Kohler, A.; Cascio, P.; Leggett, D.S.; Woo, K.M.; Goldberg, A.L.; Finley, D. The axial channel of the proteasome core particle is gated by the Rpt 2 ATPase and controls both substrate entry and product release. Mol. Cell 2001, 7, 1143-1152.

162. Yamano, T.; Murata, S.; Shimbara, N.; Tanaka, N.; Chiba, T.; Tanaka, K.; Yui, K.; Udono, H. Two distinct pathways mediated by PA28 and hsp90 in major histocompatibility complex class I antigen processing. J. Exp. Med. 2002, 196, 185-196.

163. Preckel, T.; Fung-Leung, W.-P.; Cai, Z.; Vitiello, A.; Salter-Cid, L.; Winqvist, O.; Wolfe, T.G.; von Herrath, M.; Angulo, A.; Ghazal, P.; et al. Impaired immunoproteasome assembly and immune responses in $P A 28^{-1-}$ mice. Science 1999, 286, 2162-2165.

164. Murata, S.; Udono, H.; Tanahashi, N.; Hamada, H.; Watanabe, K.; Adachi, K.; Yamano, T.; Yui, K.; Kobayashi, H.; Kasahara, M.; et al. Immunoproteasome assembly and antigen presentation in mice lacking both PA28 $\alpha$ and PA28ß. EMBO J. 2001, 20, 5898-5907.

165. Dick, T.P.; Ruppert, T.; Groettrup, M.; Kloetzel, P.M.; Kuehn, L.; Koszinowski, U.H.; Stevanovic, S.; Schild, H.; Rammensee, H.-G. Coordinated dual cleavages induced by the proteasome regulator PA28 lead to dominant MHC ligands. Cell 1996, 86, 253-262.

166. De Graaf, N.; van Helden, M.J.; Textoris-Taube, K.; Chiba, T.; Topham, D.J.; Kloetzel, P.M.; Zaiss, D.M.; Sijts, A.J. PA28 and the proteasome immunosubunits play a central and independent role in the production of MHC class I-binding peptides in vivo. Eur. J. Immunol. 2011, 41, 926-935. 
167. Groettrup, M.; Soza, A.; Eggers, M.; Kuehn, L.; Dick, T.P.; Schild, H.; Rammensee, H.-G.; Koszinowski, U.H.; Kloetzel, P.M. A role for the proteasome regulator PA28 $\alpha$ in antigen presentation. Nature 1996, 381, 166-168.

168. Schwarz, K.; Eggers, M.; Soza, A.; Koszinowski, U.H.; Kloetzel, P.M.; Groettrup, M. The proteasome regulator PA28 $\alpha / \beta$ can enhance antigen presentation without affecting $20 \mathrm{~S}$ proteasome subunit composition. Eur. J. Immunol. 2000, 30, 3672-3679.

169. Van Hall, T.; Sijts, A.; Camps, M.; Offringa, R.; Melief, C.; Kloetzel, P.-M.; Ossendorp, F. Differential influence on cytotoxic T-lymphocyte epitope presentation by controlled expression of either proteasome immunosubunits or PA28. J. Exp. Med. 2000, 192, 483-494.

170. Sijts, A.; Sun, Y.; Janek, K.; Kral, S.; Paschen, A.; Schadendorf, D.; Kloetzel, P.M. The role of the proteasome activator PA28 in MHC class I antigen processing. Mol. Immunol. 2002, 39, 165-169.

171. Sun, Y.; Sijts, A.J.A.M.; Song, M.; Janek, K.; Nussbaum, A.K.; Kral, S.; Schirle, M.; Stevanovic, S.; Paschen, A.; Schild, H.; et al. Expression of the proteasome activator PA28 rescues the presentation of a cytotoxic T-lymphocyte epitope on melanoma cells. Cancer Res. 2002, 62, 2875-2882.

172. Textoris-Taube, K.; Henklein, P.; Pollmann, S.; Bergann, T.; Weisshoff, H.; Seifert, U.; Drung, I.; Mugge, C.; Sijts, A.; Kloetzel, P.M.; et al. The N-terminal flanking region of the TRP2360-368 melanoma antigen determines proteasome activator PA28 requirement for epitope liberation. J. Biol. Chem. 2007, 282, 12749-12754.

173. Yamano, T.; Sugahara, H.; Mizukami, S.; Murata, S.; Chiba, T.; Tanaka, K.; Yui, K.; Udono, H. Allele-selective effect of PA28 in MHC class I antigen processing. J. Immunol. 2008, 181, 1655-1664.

174. Schwarz, K.; van den Broek, M.; Kostka, S.; Kraft, R.; Soza, A.; Schmidtke, G.; Kloetzel, P.-M.; Groettrup, M. Overexpression of the proteasome subunits LMP2, LMP7, and MECL-1, but not PA28 $\alpha / \beta$, enhances the presentation of an immunodominant lymphocytic choriomeningitis virus T-cell epitope. J. Immunol. 2000, 165, 768-778.

175. Nikaido, T.; Shimada, K.; Shibata, M.; Hata, M.; Sakamoto, M.; Takasaki, Y.; Sato, C.; Takahashi, T.; Nishida, Y. Cloning and nucleotide sequence of cDNA for Ki antigen, a highly conserved nuclear protein detected with sera from patients with systemic lupus erythematosus. Clin. Exp. Immunol. 1990, 79, 209-214.

176. Wilk, S.; Chen, W.E.; Magnusson, R.P. Properties of the nuclear proteasome activator PA28 $\gamma$ (REG $\gamma$ ). Arch. Biochem. Biophys. 2000, 383, 265-271.

177. Murata, S.; Kawahara, H.; Tohma, S.; Yamamoto, K.; Kasahara, M.; Nabeshima, Y.; Tanaka, K.; Chiba, T. Growth retardation in mice lacking the proteasome activator PA28\%. J. Biol. Chem. 1999, 274, 38211-38215.

178. Barton, L.F.; Runnels, H.A.; Schell, T.D.; Cho, Y.; Gibbons, R.; Tevethia, S.S.; Deepe, G.S.; Monaco, J.J. Immune defects in $28-\mathrm{kDa}$ proteasome activator $\gamma$-deficient mice. J. Immunol. 2004, 172, 3948-3954.

179. Araya, R.; Takahashi, R.; Nomura, Y. Yeast two-hybrid screening using constitutive-active caspase-7 as bait in the identification of PA28 $\gamma$ as an effector caspase substrate. Cell Death Differ. 2002, 9, 322-328.

180. Hagemann, C.; Patel, R.; Blank, J.L. MEKK3 interacts with the PA28y regulatory subunit of the proteasome. Biochem. J. 2003, 373, 71-79. 
181. Li, X.; Lonard, D.M.; Jung, S.Y.; Malovannaya, A.; Feng, Q.; Qin, J.; Tsai, S.Y.; Tsai, M.J.; O'Malley, B.W. The SRC-3/AIB1 coactivator is degraded in a ubiquitin- and ATP-independent manner by the REG $\gamma$ proteasome. Cell 2006, 124, 381-392.

182. Li, X.; Amazit, L.; Long, W.; Lonard, D.M.; Monaco, J.J.; O’Malley, B.W. Ubiquitin- and ATP-independent proteolytic turnover of p21 by the REG $\gamma$-proteasome pathway. Mol. Cell 2007, 26, 831-842.

183. Levy-Barda, A.; Lerenthal, Y.; Davis, A.J.; Chung, Y.M.; Essers, J.; Shao, Z.; van Vliet, N.; Chen, D.J.; Hu, M.C.; Kanaar, R.; et al. Involvement of the nuclear proteasome activator PA28 $\gamma$ in the cellular response to DNA double-strand breaks. Cell Cycle 2011, 10, 4300-4310.

184. Zannini, L.; Lecis, D.; Buscemi, G.; Carlessi, L.; Gasparini, P.; Fontanella, E.; Lisanti, S.; Barton, L.; Delia, D. REG $\gamma$ proteasome activator is involved in the maintenance of chromosomal stability. Cell Cycle 2008, 7, 504-512.

185. Baldin, V.; Militello, M.; Thomas, Y.; Doucet, C.; Fic, W.; Boireau, S.; Jariel-Encontre, I.; Piechaczyk, M.; Bertrand, E.; Tazi, J.; et al. A novel role for PA28 $\gamma$-proteasome in nuclear speckle organization and SR protein trafficking. Mol. Biol. Cell 2008, 19, 1706-1716.

186. Zhang, Z.; Zhang, R. Proteasome activator PA28 $\gamma$ regulates p53 by enhancing its MDM2-mediated degradation. EMBO J. 2008, 27, 852-864.

187. Liu, J.; Yu, G.; Zhao, Y.; Zhao, D.; Wang, Y.; Wang, L.; Li, L.; Zeng, Y.; Dang, Y.; Wang, C.; et al. REG $\gamma$ modulates p53 activity by regulating its cellular localization. J. Cell. Sci. 2010, 123, 4076-4084.

188. Li, L.; Zhao, D.; Wei, H.; Yao, L.; Dang, Y.; Amjad, A.; Xu, J.; Liu, J.; Guo, L.; Li, D.; et al. REG $\gamma$ deficiency promotes premature aging via the casein kinase 1 pathway. Proc. Natl. Acad. Sci. USA 2013, 110, 11005-11010.

189. Wan, Z.X.; Yuan, D.M.; Zhuo, Y.M.; Yi, X.; Zhou, J.; Xu, Z.X.; Zhou, J.L. The proteasome activator PA28 $\gamma$, a negative regulator of $\mathrm{p} 53$, is transcriptionally up-regulated by p53. Int. J. Mol. Sci. 2014, 15, 2573-2584.

190. Realini, C.; Jensen, C.C.; Zhang, Z.; Johnston, S.C.; Knowlton, J.R.; Hill, C.P.; Rechsteiner, M. Characterization of recombinant REG $\alpha$, REG $\beta$, and REG $\gamma$ proteasome activators. J. Biol. Chem. 1997, 272, 25483-25492.

191. Hoffman, L.; Pratt, G.; Rechsteiner, M. Multiple forms of the $20 \mathrm{~S}$ multicatalytic and the $26 \mathrm{~S}$ ubiquitin/ATP-dependent proteases from rabbit reticulocyte lysate. J. Biol. Chem. 1992, 267, 22362-22368.

192. Blickwedehl, J.; Agarwal, M.; Seong, C.; Pandita, R.K.; Melendy, T.; Sung, P.; Pandita, T.K.; Bangia, N. Role for proteasome activator PA200 and postglutamyl proteasome activity in genomic stability. Proc. Natl. Acad. Sci. USA 2008, 105, 16165-16170.

(C) 2014 by the authors; licensee MDPI, Basel, Switzerland. This article is an open access article distributed under the terms and conditions of the Creative Commons Attribution license (http://creativecommons.org/licenses/by/4.0/). 